\title{
UNIVERSITYOF
}

FORWARD

THINKING

WESTMINSTER用

WestminsterResearch

http://www.westminster.ac.uk/westminsterresearch

\section{Young people's labour market transitions: the role of early experiences}

Dorsett, R. and Lucchino, P.

NOTICE: this is the authors' version of a work that was accepted for publication in Labour Economics. Changes resulting from the publishing process, such as peer review, editing, corrections, structural formatting, and other quality control mechanisms may not be reflected in this document. Changes may have been made to this work since it was submitted for publication. A definitive version was subsequently published in Labour Economics, DOI:10.1016/j.labeco.2018.06.002, 2018.

The final definitive version in Labour Economics is available online at:

https://dx.doi.org/10.1016/j.labeco.2018.06.002

(C) 2018. This manuscript version is made available under the CC-BY-NC-ND 4.0 license https://creativecommons.org/licenses/by-nc-nd/4.0/

The WestminsterResearch online digital archive at the University of Westminster aims to make the research output of the University available to a wider audience. Copyright and Moral Rights remain with the authors and/or copyright owners.

Whilst further distribution of specific materials from within this archive is forbidden, you may freely distribute the URL of WestminsterResearch: ((http://westminsterresearch.wmin.ac.uk/)).

In case of abuse or copyright appearing without permission e-mail repository@westminster.ac.uk 


\title{
Young people's labour market transitions: the role of early experiences
}

\author{
Richard Dorsett ${ }^{\mathrm{a}}$ and Paolo Lucchino ${ }^{\mathrm{b}}$
}

13 June 2018

\begin{abstract}
We use UK longitudinal survey data to model young people's transitions between employment, unemployment, education and a residual category made up of those neither in education nor economically active. Transitions from employment are shown to exhibit negative duration dependence regardless of destination, while transitions from unemployment only do so when the destination is employment. The results suggest the nature and length of males' preceding spells affect transitions from unemployment to employment but that this is not the case for females. The combination of modelled effects is captured through simulations. These show that, for both males and females, a period neither in education nor economically active has more damaging long-term consequences for future employment than a period of unemployment.
\end{abstract}

Keywords: young people; labour market transitions; duration dependence; lagged duration dependence; unobserved heterogeneity

JEL codes: C33, C41, J64

\section{Acknowledgements}

The authors are grateful for financial support from the Nuffield Foundation (contract EDU/39082). Earlier versions of the paper were presented at the 2012 conferences of the Royal Economic Society, the European Society of Population Economics and the European Association of Labour Economists; at the IFS workshop on applied policy evaluation; at the MiSOC Growing up in recession Britain conference; at the NIESR workshop Understanding and influencing young people's early labour market experiences, and at seminars for officials from several UK government departments. We are grateful for all comments and suggestions received, including those from two anonymous referees. Any errors and all interpretations are those of the authors alone.

${ }^{a}$ Corresponding author. University of Westminster, 309 Regent Street, London W1B 2HW, UK. Email: r.dorsett@westminster.ac.uk.

${ }^{\mathrm{b}}$ Independent researcher 


\section{Introduction}

The main characteristic distinguishing young workers from their older counterparts is a lack of employment experience. Until they acquire this, young people's position in the labour market is relatively tenuous. For instance, an employer facing the need to reduce staff numbers may view the loss of younger workers as less damaging than the loss of older workers, whose general and firm-specific skills are costlier to replace. Similarly, a lack of experience makes it more difficult for young people to compete against prime-age workers when searching for jobs. Compounding this, less experienced workers are often less covered by employment protection legislation; their notice period is, in many countries, a function of job seniority.

Acquiring employment experience - and thereby skills - is key to a successful transition from education to employment. Its impact is of interest to those seeking to understand labour market processes. For instance, active labour market programmes - a mainstay of labour market policy - often seek to improve employment and earnings prospects through work placements. However, estimating the impact of experience is complicated by its inherently dynamic nature. Heterogeneity among young people results in the subgroup of those experiencing long periods out of work being qualitatively different from the subgroup who do not have that same experience (Eberwein et al., 1997). Comparing the longer-term labour market outcomes of these two subgroups conflates that heterogeneity (typically unobservable to the analyst) with the causal impact that a long period of worklessness may have.

Empirical studies have sought to isolate the causal effect of different types of experience. Duration dependence refers to the causal impact that the length of time in a state unemployment, for instance, or employment - has on the probability of subsequently exiting that state. Kalwij (2004) provides evidence of negative duration dependence among young men's transitions out of unemployment in the UK. In other words, the length of time unemployed causally reduces the rate of exit. This may be explained by skill deterioration (Pissarides 1992), employer discrimination (Blanchard and Diamond 1994, Lockwood 1991, Vishwanath 1989) or social networks as a source of employment becoming exhausted (Calvo-Armengol and Jackson 2004). Kalwij (2004) also finds negative duration dependence in employment exits, perhaps due to individuals acquiring valued skills on the job or firms organising layoffs on a 'first in, last out' principle (Kiefer and Neumann 1989). 
There may also be longer-term effects. Successive UK studies point to the scarring effects of unemployment (Arulampalam 2001, Arulampalam et al. 2000, Stewart 2007) and evidence exists to suggest that unemployment when young can have negative impacts on adult outcomes including unemployment (Burgess et al. 2003, Gregg 2001) and wages (Gregg and Tominey 2005).

In this paper, we consider young people's behaviour in the labour market and examine the causal impact of early experience. The analysis is based on an econometric model of transitions between four states: employment, unemployment, education and a residual category made up of people who are neither studying nor economically active, which we refer to as NEA (Neither in Education nor Active). Transitions between these states form the dependent variables while past realisations of the states are included as regressors summarising prior labour market experience. By controlling for unobserved heterogeneity, our results provide causal estimates of the impact of differing types of experience.

We provide new insights highlighting the behavioural distinction between unemployment and NEA. As such, the results build on a literature that began with Flinn and Heckman (1983). That study was based on a very small sample; 122 young men, selected to exclude any who returned to education. Others since then have estimated transition models that distinguish between unemployment and inactivity; see, for example, Bonnal et al. (1997) and Jones and Riddell (2006). NEA, a subgroup within overall inactivity, is not separately identified by these studies. By recognising four states, the analysis in this paper extends these results, permitting individuals to return to study but also allowing the initial decision to leave school to be endogenously determined. The results allow sharp focus on the distinction between unemployment and NEA.

The econometric model is specified to capture cross-spell effects, thereby allowing an explicit channel through which experience can influence later transition probabilities. A number of studies have examined some aspects of this for young people (for example, Bonnal et al. 1997; Bratberg and Nilsen 2000; Mroz and Savage 2006; Cockx and Picchio 2012, 2013). For the UK the most relevant evidence is Kalwij (2004) who considers transitions into and out of claimant unemployment. Again, our results provide richer insights by allowing a larger number of states to be considered. We present evidence on how the prior experience of employment, unemployment and NEA influence transitions into work, and the extent to which that varies depending on the length of these prior spells. 
Methodologically, this paper is closest to Doiron and Gørgens (2008), who study transitions between employment, unemployment and inactivity among Australian youth between 1989 and 1994. They allow preceding status to affect transition intensities in the current spell but also for cumulative experience terms (total time spent in employment, for example) to have an effect. Also similar is Cockx and Picchio (2012), who model Belgian school-leavers' transitions between unemployment, employment and an absorbing other state (including leaving the labour force), alongside job-to-job transitions. They allow for effects of preceding status, lagged duration dependence and occurrence dependence.

Relative to Doiron and Gørgens (2008) and Cockx and Picchio (2012), the main contribution of the analysis reported in this paper is that it considers four possible states and thereby allows a distinction to be made between those in education and those out of the labour force for other reasons (a group of particular policy interest). Furthermore, an advance over the other studies is that it allows for endogeneity of the school-leaving decision. With regard to the role of prior labour market experience, we follow Cockx and Picchio (2012) in excluding cumulative experience on the grounds of there being no formal identification result that allows such effects to be interpreted causally. Instead, we allow for the effects of preceding status and lagged duration dependence.

The paper proceeds as follows. Section 2 describes the data used. The econometric model is presented in section 3 , with results given in section 4 . Section 5 concludes.

\section{Data}

The analysis is based on the British Household Panel Survey (BHPS), a nationally representative annual longitudinal survey that ran from 1991 until 2008. All eighteen waves of data are used, covering the period up to 2008. The design of the BHPS is such that children within sampled households become eligible for full (adult) interviews once they reach the age of 16 and, thereafter, are interviewed annually. We restrict our attention to those observed to turn 16 at any time between 1991 and 2008. To retain the focus on the youth labour market, we right-censor observations at the point of reaching age 25 .

The estimation dataset uses monthly labour market and education histories that run from the month before individuals are legally allowed to leave school (in this first month, all 
individuals are in education). ${ }^{1}$ An individual's status in each month is defined according to his or her own self-reported main activity, selected from a list of ten available choices. These activities are then grouped into the four states under consideration: Employment, Unemployment, NEA and Education. ${ }^{2}$

Transitions are estimated separately for males and females. All transitions are allowed to vary with age, whether the individual is a mother and a range of variables defined at age 16: qualification level, health problem, household income, parental qualification and parental employment. Season dummies are also included. Local labour market effects are captured using the monthly claimant unemployment rate in the individual's local authority, expressed as a deviation from the national average. This deviation form was chosen in order to control for changes over time in the rules governing receipt of out of work benefits. The intuition is that while institutional changes reduce the usefulness of the unemployment benefit series as a measure of the business cycle, cross-sectional differences remain important as a means of capturing geographic variations in the strength of the labour market. Effects of the business cycle are instead captured using estimates of monthly (national) GDP (Mitchell et al. 2005). As discussed below, exogenous geographic variation (in the case of local unemployment) and temporal variation (in the case of both local unemployment and GDP) provide another source of model identification. ${ }^{3}$

Selected descriptive statistics for the sample when first observed are given in Table 1. We note that, at this point, everyone in the sample is in their final month of compulsory schooling. Academic years in the UK begin in September and pupils must remain in school until June in the academic year in which they turn 16. In practice, this means that most children are 16 by the time they are able to leave school. Reflecting this, Table 1 shows that the mean age was slightly below 16 during the last month of compulsory schooling. Another

\footnotetext{
${ }^{1}$ We follow Maré (2006) and Paull (2002) who provide detailed accounts of how to construct monthly labour market histories from the BHPS.

${ }^{2}$ The original ten states are: 1) self-employed 2) employed 3) unemployed 4) retired 5) maternity leave 6) family carer 7) full-time student 8) long-term sick/disabled 9) Government training scheme 10) other. Our groupings are: Employed =1, 2 or 5; Unemployed = 3 or 9; NEA = 4, 6, 8 or 10; Education = 7. As Paull (2002) notes, where individuals are engaged in more than one activity in a month, there will be an element of subjectivity in the choice of activity they report. Note that the education category is made up of full-time students and excludes individuals on training programmes. We ignore breaks in education spells of up to 2 months in order to ensure that school holidays are not recorded as NEA. Self-employment is uncommon in this age group (accounting for 3 and 1 per cent of male and female Employment spells, respectively) and so cannot be separately analysed.

${ }^{3} 380$ local authorities are represented in the data.
} 
point worth highlighting in Table 1 is that around one third of the overall sample (slightly higher for females than males) have 8 or more high-grade GCSEs. ${ }^{4}$ This is a level of qualification commensurate with continuing comfortably into higher education. At the other extreme, 11 per cent have no qualifications and 16 and 11 per cent of males and females respectively have only a CSE. ${ }^{5}$ Parental qualifications are shown differently, converted to NVQ "equivalents". ${ }^{6}$ On this basis, roughly one-fifth of children have parents with no qualifications.

Table 1 also describes the spell structure of the estimation dataset. In total, we have information on nearly 3,500 individuals and more than 11,000 separate spells. This represents a mean of 3.3 and 3.4 spells for males and females respectively, with a median of 3 . On average, respondents were observed for more than 50 months.

\footnotetext{
${ }^{4}$ General Certificate of Secondary Education, the standard age-16 qualification.

${ }^{5}$ Certificate of Secondary Education, a low-level qualification.

${ }^{6}$ National Vocational Qualifications. Converting all qualifications to NVQ equivalents allows academic and vocational qualifications to be considered on the same scale.
} 
Table 1: Summary statistics

Characteristics at age 16

Males

Age

15.81

Females

Non-white

0.05

15.81

Qualifications:*

- 8 or more A-C grade GCSES

$\begin{array}{ll}0.29 & 0.36 \\ 0.12 & 0.13 \\ 0.32 & 0.29 \\ 0.16 & 0.11 \\ 0.11 & 0.11 \\ 0.82 & 0.78\end{array}$

- 5-7 A-C grade GCSEs

13

- 1-4 A-C grade GCSES

0.11

- CSE

0.11
0.78

Living in working household

0.82

0.28

- NVQ level 4

0.28

0.14

- NVQ level 3

0.15

0.09

- NVQ level 2

0.1

0.28

- NVQ level 1

0.29

0.21

- None

0.18

1,811

Number of individuals

1,663

Spell characteristics

Number of spells

5560

6193

Number of spells per person

$-1$

369

432

$-2$

484

437

$-3$

223

248

$-4$

210

241

$-5$

118

133

$-6$

96

119

$-7$

44

64

$-8$

35

55

$-9$

31

23

$-10+$

53

59

- mean

3.3

3.4

- median

2

3

- max

22

18

Number of months observed

- mean

51.9

55

- median

- max

111

111

*The GCSE (General Certificate of Education) is the main age 16 academic qualification. The CSE (Certificate of Secondary Education) was a lower-level qualification that preceded the GCSE.

** The NVQ (National Vocational Qualification) is a work-based qualification. Parental qualification has been expressed in NVQ equivalents, in order to provide a measure covering both academic and vocational qualifications. 
Table 2 shows that employment and education spells are more numerous than other spell types. Unemployment spells are roughly half in number. NEA spells are the least common but show a gender difference; the proportion of all female spells that are NEA is double that for males. Education spells have the longest median duration (13 months for both males and females), followed by employment (11 months for males, 12 for females). Unemployment spells are the shortest (a median of 3 months for males and females). NEA spells also have a median duration of 3 months for males, but are considerably longer for females, with a median of 7 months.

Table 2: Spell length (in months) by origin state

\begin{tabular}{|c|c|c|c|c|}
\hline & Employment & Unemployment & NEA & Education \\
\hline & \multicolumn{4}{|c|}{ Males } \\
\hline Mean spell length & 20.5 & 5.9 & 6.5 & 17.3 \\
\hline \multicolumn{5}{|l|}{ Deciles } \\
\hline-10 & 1 & 1 & 1 & 1 \\
\hline-20 & 2 & 1 & 2 & 2 \\
\hline-30 & 4 & 2 & 2 & 4 \\
\hline-40 & 7 & 3 & 3 & 7 \\
\hline-50 & 11 & 3 & 3 & 13 \\
\hline-60 & 14 & 4 & 5 & 16 \\
\hline-70 & 23 & 6 & 7 & 23 \\
\hline-80 & 35 & 8 & 10 & 28 \\
\hline-90 & 61 & 13 & 13 & 41 \\
\hline Right-censored (\%) & 47.0 & 15.6 & 15.2 & 23.8 \\
\hline \multirow[t]{2}{*}{$\mathrm{N}$} & 1,988 & 1,188 & 264 & 2,120 \\
\hline & \multicolumn{4}{|c|}{ Females } \\
\hline Mean spell length & 19.7 & 5.5 & 14.2 & 18.1 \\
\hline \multicolumn{5}{|l|}{ Deciles } \\
\hline-10 & 1 & 1 & 1 & 1 \\
\hline-20 & 3 & 1 & 2 & 2 \\
\hline-30 & 5 & 2 & 3 & 4 \\
\hline-40 & 8 & 3 & 4 & 9 \\
\hline-50 & 12 & 3 & 7 & 13 \\
\hline-60 & 15 & 4 & 10 & 17 \\
\hline-70 & 23 & 6 & 13 & 24 \\
\hline-80 & 34 & 9 & 22 & 29 \\
\hline-90 & 53 & 12 & 37 & 45 \\
\hline Right-censored (\%) & 44.0 & 12.2 & 27.9 & 24.2 \\
\hline $\mathrm{N}$ & 2,116 & 1,070 & 584 & 2,423 \\
\hline
\end{tabular}


These summary descriptives provide an early indication of the importance of distinguishing between unemployment and NEA. This impression is reinforced by Figure 1 which illustrates the extent to which the rate of exits from an initial state changes over the course of the spell. The graphs on the leading diagonal are the empirical (Kaplan-Meier) survival curves for employment, unemployment, NEA and education spells, respectively. These show negative duration dependence in exits from all states. This is most marked in the case of unemployment and NEA spells, although males exit NEA at a faster rate than females. Education exits are particularly concentrated in the first month. This partly reflects those individuals who leave school at the earliest opportunity. However, the fact that education spells are defined to include both school and subsequent education following a break in study reduces the extent to which school-leavers alone determine the shape of the survival curve.

The survival curves reveal important gender differences in NEA exits. Long-term NEA spells are shown to be more common among females than males (for whom exit patterns resemble those seen for unemployment spells). This perhaps reflects the high incidence of parenthood among young NEA women; their childcare responsibilities may prevent economic activity or participation in education. Employment is the only other state that exhibits gender differences in exits. This is only evident at longer durations, where exits among female workers occur more commonly than among male workers. This may be capturing women leaving the labour force to bring up children, as they progress into their twenties. ${ }^{7}$

Since exits can be to one of three alternative states, it is helpful to examine how transition rates to a specific destination alter over the course of the spell. The off-diagonal charts in Figure 1 plot the cumulative incidence curves, that is, the probability of having exited the initial state (in the row) to a specific destination (in the column) as the spell lengthens. ${ }^{8}$

These charts provide additional insight into the nature of transitions. Exits from employment to unemployment and education are concentrated in the earliest months of a spell while exits from employment to NEA occur steadily over time but at a slow rate. For the unemployed, by far the most common exit destination is employment, with a heavy concentration in the earlier months. The inference appears to be that those who do not find work relatively quickly are unlikely to do so at all. Fewer NEA spells end with a move into employment although,

\footnotetext{
${ }^{7}$ These patterns are discussed in more detail in Dorsett and Lucchino (2014).

${ }^{8}$ The calculation and properties of cumulative incidence curves are described in Coviello and Boggess (2004).
} 
again, there is a concentration towards the start of the spell. Unemployment and NEA appear qualitatively distinct, with moves between the two tending to be rare. Education is a somewhat more important destination for NEA spells, particularly for females. Lastly, exits from education into any of the three other states do not appear to be so heavily concentrated in the early months of the spell.

Figure 1: Survival curves and cumulative incidence curves
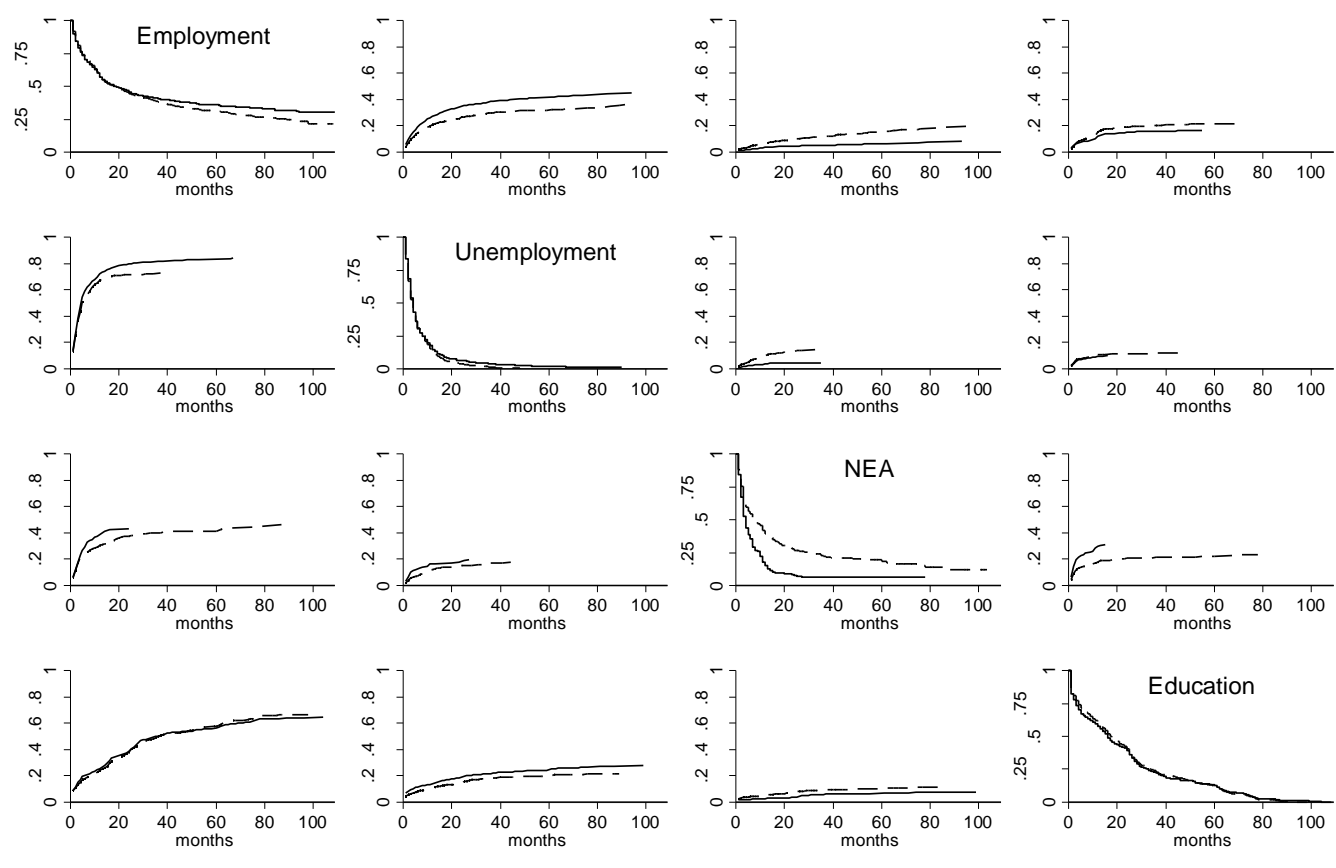

Male



Note: the charts on the leading diagonal show the Kaplan-Meier survival curves for the named origin states. Off-diagonal charts show cumulative incidence curves; the probability of having exited the initial state (in the row) to a specific destination (in the column) as the spell lengthens.

The number of transitions between states is summarised in Table 3. Again, the distinction between unemployment and NEA status is evident; 64 per cent of males become unemployed on exiting employment but only 9 per cent become NEA. For females, the corresponding percentages (47 and 20) further underscore the gender difference. The importance of allowing for returns to education is apparent; this accounts for 26 and 32 per cent of observed employment exits for males and females respectively. With regard to unemployment exits, the dominant destination is employment. This accounts for 85 per cent of unemployment exits for males and 75 percent for females. The discrepancy is accounted for by a higher rate of transitions into NEA for females (13 per cent of unemployment exits, compared to 5 per 
cent for males). NEA spells end with a job in about 50 per cent of cases overall, slightly higher for females than males. Lastly, nearly two-thirds of those leaving education will enter employment. This is common across both sexes but among those not finding work, unemployment is somewhat more prevalent for males than females (who, correspondingly, are more likely than males to be NEA).

Table 3: Flows between states, row percentages

\begin{tabular}{lccccc}
\hline Origin: & $\begin{array}{c}\text { Destination: } \\
\text { Employment }\end{array}$ & Unemployment & $\begin{array}{r}\text { NEA } \\
\text { Males }\end{array}$ & Education & $\mathrm{N}$ \\
Employment & - & 0.64 & 0.09 & 0.26 & 1,054 \\
Unemployment & 0.85 & - & 0.05 & 0.10 & 1,003 \\
NEA & 0.46 & 0.20 & - & 0.34 & 224 \\
Education & 0.64 & 0.29 & 0.07 & - & 1,616 \\
$\mathrm{~N}$ & 1,988 & 1,188 & 264 & 457 & 3,897 \\
& & & Females & & \\
Employment & - & 0.47 & 0.20 & 0.32 & 1,186 \\
Unemployment & 0.75 & - & 0.13 & 0.12 & 939 \\
NEA & 0.52 & 0.21 & - & 0.28 & 421 \\
Education & 0.65 & 0.23 & 0.12 & - & 1,836 \\
$\mathrm{~N}$ & 2,116 & 1,070 & 584 & 612 & 4,382 \\
\hline
\end{tabular}

\section{Empirical approach}

\subsection{The econometric model}

We estimate a multi-state model to examine transitions between four mutually exclusive and exhaustive activity states: work $(w)$, unemployment $(u)$, NEA $(n)$ and education $(e)$. We write the transition intensity from origin state $j$ to destination state $k$ as $\theta_{j k}$. There are twelve possible types of transition: $\{w \rightarrow u, w \rightarrow n, w \rightarrow e, u \rightarrow w, u \rightarrow n, u \rightarrow e, n \rightarrow w, n \rightarrow$ $u, n \rightarrow e, e \rightarrow w, e \rightarrow u, e \rightarrow n\}$.

The econometric challenge is to control for unobserved heterogeneity. As first shown by Lancaster (1979), not to do so will result in duration dependence being over-estimated. This arises due to sorting effects whereby individuals with an unobserved characteristic that increases exit rates leave the origin state earlier than those without that characteristic, so that observed exit rates decline with the length of spell. By controlling for unobserved heterogeneity, we aim to identify genuine duration dependence whereby remaining in a state 
for a longer period of time in itself reduces the rate of exit. The consideration of prior experience raises similar issues: unobserved characteristics may influence past outcomes in a similar way to how they influence later outcomes (Heckman and Borjas 1980). For instance, individuals who are highly motivated might be expected to have consistently different outcomes from individuals who are not. If we wish to argue that estimates of the impact of prior experience on subsequent transitions can be given a causal interpretation, the econometric model must control for correlation across transition types in unobserved characteristics. We attempt to capture the effect of prior experience by including dummy variables identifying the individual's state immediately prior to their current state and other variables capturing the duration of the individual's previous spell in that state (lagged duration dependence).

As already noted, all individuals in our sample are first observed in their last month of compulsory education. In the following month, they are legally allowed to leave school and three types of transition become possible: beginning work, becoming unemployed or entering a NEA spell. Alternatively, they may remain in education. Similarly, in each subsequent month, individuals face the competing risks of entering one of the other states or, alternatively, remaining in their current state.

An important advantage of our approach is that including education as one of the states of interest avoids the need to impose restrictions that could affect the representativeness of the results. Doiron and Gørgens (2008), for example, model transitions after leaving school and therefore treat the age at which individuals leave school as exogenous. We model transitions from education - including the first transition - and so the endogeneity of individuals' decisions about when to leave school (or, indeed, later education) is addressed. Similarly, modelling transitions into education avoids the need to exclude from the estimation sample those individuals observed to return to education following a spell in an alternative state (Doiron and Gørgens 2008) or to treat such transitions as a form of censoring (Cockx and Picchio 2012). ${ }^{9}$

\footnotetext{
${ }^{9}$ Ideally, our model would distinguish between different types of education (school, university, etc). Our ability to do this is limited by the data and the fact that introducing an additional state would increase the number of transition types from 12 to 20 , making the model considerably more complex. Instead, we include age variables in the model that are intended to distinguish between usual ages of secondary education, university education and post-tertiary education.
} 
We follow van den Berg and van der Klaauw (2001) and specify the discrete-time process as having an underlying continuous-time mixed proportional hazard (MPH) form. Integrating the continuous-time outcomes over the observation intervals of calendar months, the transition intensity from $j$ to $k(j \neq k)$ can be written with a mixed proportional hazard (MPH) form:

$$
\theta_{j k}\left(t \mid \mathbf{x}, v_{j k}, a_{l a g}, t_{l a g}\right)=h_{j k}(t) \phi_{j k}(\mathbf{x}) \psi_{j k}\left(a_{l a g}, t_{l a g}\right) v_{j k}
$$

Here, $a_{\text {lag }}$ is the activity immediately preceding the current spell and $t_{\text {lag }}$ is the length of that previous spell. $h_{j k}(t)$ is the baseline transition intensity. We adopt a hybrid approach to specifying the baseline hazard, which attempts to balance the desire for flexibility where possible (and of most interest) against the need for a functional form assumption for those transition types or transition durations for which there are few observations. To do this, we assume a parametric (quadratic) functional form for duration dependence and include additional dummies to augment this with discrete shifts as appropriate. This parametricpiecewise transition intensity can be expressed generally as

$$
h_{j k}(t)=\exp \left(\gamma_{j k}^{1} t+\gamma_{j k}^{2} t^{2}+\sum_{b=1}^{B_{j k}} \gamma_{j k}^{b} 1\left(\tau_{b-1} \leq t<\tau_{b-1}\right)\right)
$$

where $B_{j k}$ is the number of segments and $\tau_{0}=0$ and where relevant coefficients can be set to zero to tailor to a specific transition intensity. For each transition type, the segments were chosen to ensure a sufficient number of transitions were observed within each one. Due to variation in the numbers experiencing each transition type, this means that the segmentation of the baseline hazard is coarser for some transition types than for others.

The systematic part of the hazard is specified as

$$
\phi_{j k}(\mathbf{x})=\exp \left(\mathbf{x} \beta_{j k}\right)
$$

Here, $\mathbf{x}$ includes both fixed characteristics (at age 16: qualifications, health, parental qualifications, household income and whether parent was working) and time-varying characteristics (age, whether any dependent children (for females), calendar season, local unemployment rate (deviation from national average) and deviation from trend monthly GDP). The lagged dependencies are specified: 


$$
\psi_{j k}\left(a_{\text {lag }}, t_{l a g}\right)=\exp \left(\sum_{p \neq j} \alpha_{j k}^{p} 1\left(a_{\text {lag }}=p\right)+\sum_{q \neq j} \delta_{j k}^{q} 1\left(a_{l a g}=q\right) \ln \left(t_{l a g}\right)\right)
$$

Lastly, the specification allows for unobserved heterogeneity, $v_{j k}$, where the subscript indicates that this may affect different types of transitions differently. Individual unobserved heterogeneity is assumed fixed across spells of each type.

The contribution to the likelihood of individual $i$ 's censored spell of length $d$ is:

$$
L_{i}^{c e n s}\left(\mathbf{v}_{i j}\right)=\prod_{r=1}^{d} \exp \left(-\sum_{(j, k) \in \mathcal{J}} \theta_{j k}(r)\right)
$$

where $\mathcal{J}=\{(w, u),(w, n),(w, e)\}$ if $j=w, \mathcal{J}=\{(u, w),(u, n),(u, e)\}$ if $j=u, \mathcal{J}=$ $\{(n, w),(n, u),(n, e)\}$ if $j=n, \mathcal{J}=\{(e, w),(e, u),(e, n)\}$ if $j=e$ and $\mathbf{v}_{i j}$ collects the unobserved heterogeneity terms associated with the transition from state $j$ to state $k$ for individual $i$. For compactness, the conditioning of the transition intensities is left implicit.

The contribution of individual $i$ 's complete spell, with a transition from $j$ to $k$ at duration $d$, is:

$$
L_{i}^{c o m p}\left(\mathbf{v}_{i j}\right)=\left[1-\exp \left(\sum_{(j, k) \in \mathcal{J}} \theta_{j k}(d)\right)\right] \times \frac{\theta_{j k}(d)}{\sum_{(j, k) \in \mathcal{J}} \theta_{j k}(d)} \prod_{r=1}^{d-1} \exp \left(-\sum_{(j, k) \in \mathcal{J}} \theta_{j k}(r)\right) .
$$

Hence, the contribution to the likelihood of individual $i$ 's spell $s$ of $d$ months with origin state $j$ can be written generally as

$$
\begin{aligned}
L_{i}^{S}\left(\mathbf{v}_{i j}\right)=\prod_{(j, k) \in \mathcal{J}}\left[\left(1-\exp \left(\sum_{(j, k) \in \mathcal{J}} \theta_{j k}(d)\right)\right) \frac{\theta_{j k}(d)}{\sum_{(j, k) \in \mathcal{J}} \theta_{j k}(d)}\right]^{y_{i, j, k)}^{s}} \\
\times \prod_{r=1}^{d-\sum_{k} y_{i,(j, k) \in \mathcal{J}}^{s}} \exp \left(-\sum_{(j, k) \in \mathcal{J}} \theta_{j k}(r)\right)
\end{aligned}
$$


where $y_{i,(j, k)}^{S}$ is a dummy variable taking the value 1 if individual $i$ 's spell $s$ that began in state $j$ resulted in a transition to state $k$ (zero otherwise). We write the product of each of individual $i$ 's $S_{i}$ labour market spells as $L_{i}\left(\mathbf{v}_{i}\right)$, the overall likelihood contribution for individual $i$, conditional on unobserved heterogeneity.

The twelve possible transition types in the multi-state model give an unobserved heterogeneity distribution that is also of dimension twelve. We follow Heckman and Singer (1984) and discretely approximate the unobserved heterogeneity joint distribution by $M$ mass points, $v^{m}, m=1,2, \ldots, M$, where $v^{m}=$ $\left\{v_{w u}, v_{w n}, v_{w e}, v_{u w}, v_{u n}, v_{u e}, v_{n w}, v_{n u}, v_{n e}, v_{e w}, v_{e u}, v_{e n}\right\}$. The probability attached to $v^{m}$ is specified as $p^{m}=\exp \left(\lambda^{m}\right) / \sum_{g=1}^{M} \exp \left(\lambda^{g}\right), \quad m=1, \ldots, M$, where $\lambda^{1}=0$. The number of mass points, $M$, is unknown a priori but chosen on the basis of specification tests.

Denoting by $L_{i}^{m}$ the likelihood contribution associated with mass point $m$ for individual $i$, the unconditional likelihood function across the full sample of $N$ individuals is:

$$
L=\prod_{i=1}^{N} \sum_{m=1}^{M} p^{m} L_{i}^{m} .
$$

An important feature of our estimation sample is that it is subject to substantial attrition; 46 per cent of individuals drop out of the sample before age 25. Should the influences on attrition also affect transitions between labour market states, estimating the model for those individuals who remain in the sample may yield biased results. To explore this, we previously modelled sample attrition, allowing for unobserved influences to correlate with unobserved influences on labour market transitions (in the spirit of van den Berg and Lindeboom 1998). These results were very similar to those taking no account of attrition, consistent with the findings from other studies using the same data (e.g. Cappellari and Jenkins 2004 and, more recently, Cai et al. 2018). In view of this, and the already-complex nature of the econometric model, the auxiliary attrition equation was excluded from the model.

\subsection{Identification}

Horny and Picchio (2010) show that, under the MPH assumption, both the unobserved heterogeneity distribution and the structural parameters of the model - including the lagged 
dependences - are non-parametrically identified. To further assist identification, we restrict the specification of hazards to be similar across multiple spells of the same type. Brinch (2007) proves that exogenous variation in covariates over time and across individuals is sufficient for identification, without the need for proportionality. We include in our model calendar quarter dummies, the monthly local unemployment rate relative to the national rate and GDP at the national level. These series vary exogenously over time and, in the case of local unemployment, by local authority area. Furthermore, due to differences between individuals in when they start each spell and the fact that we observe multiple spells of differing durations, there is variation in these covariates across individuals at the same point in their spell. This provides another source of identification and thereby reduces reliance on the assumption of proportionality.

Lastly, we note that most identification results relate to continuous time processes. Gaure et al. (2007) provide extensive Monte Carlo evidence that the parameters of the underlying continuous time model can be recovered using discrete data, so long as the likelihood function reflects the discrete nature of the available data.

\section{Results}

This section presents the key results. ${ }^{10}$ A particular focus is on comparing unemployment and NEA. We consider both duration dependence and the lasting effects of experiencing either of these states. We also examine whether prior experience of employment changes the probability of moving from unemployment or NEA into work.

Unobserved heterogeneity in our model is represented by $M=3$ points of support for males and by $M=4$ points of support for females. ${ }^{11}$ Essentially, the model approximates the distribution of unobserved heterogeneity by assuming individuals fall into $M$ groups, with members of each group identical with regard to unobserved characteristics. The size of each group is shown at the end of Table A1a for males and Table A1b for females.

\footnotetext{
${ }^{10}$ The full estimation results are given in the Appendix.

${ }^{11}$ Estimation began with a model without unobserved heterogeneity. The coefficient estimates from this were used as starting values to estimate a model with $M=2$ points of support, with the unobserved heterogeneity starting values generated as random numbers. The $M=2$ results were in turn used as starting values in a model with $M=3$, although again using random numbers for the unobserved heterogeneity starting values. Where mass point estimates veered towards zero, they were constrained to be zero in the next estimation. With the aim of achieving the richest possible characterisation of the unobserved heterogeneity distribution, this process of incrementing $M$ continued until convergence could no longer be achieved. For males this resulted in a final specification with $M=3$ and for females it resulted in a final specification with $M=4$.
} 
We begin by providing some indication of the fit of the model. Figure 2 shows the changing activity profile from the month after reaching school-leaving age up to age 24 . The actual proportion accounted for by each state is shown with a solid line. Alongside this is a dashed line showing the corresponding simulated proportion.

The simulation approach is as follows. We take a draw from the multivariate normal distribution with means corresponding to the estimated coefficients reported in Table A1a (for males) or Table A1b (for females) and variance given by the associated variancecovariance matrix. Using this draw, labour market trajectories are simulated for all males or all females in the sample. The first month for which outcomes are simulated is the month of reaching school-leaving age (this is the first month for which individuals can be in a state other than education). ${ }^{12}$ In each subsequent month, transition intensities are re-calculated and used to simulate exits from the current state to an alternative state. The endogenous timevarying covariates (such as the state occupied prior to the current state) are updated consistent with simulated outcomes. The proportion of the sample simulated to be in each of the states in each month is saved. The whole process is then repeated 999 times, resulting in 1,000 simulations.

For males, the overall impression from Figure 2 is that the simulated proportions are, for the most part, quite similar to the observed levels. The biggest divergence arises at the time of higher education participation, roughly during the third to fifth years following schoolleaving age. During this period, simulated employment is elevated in comparison to actual levels while simulated education is lower. Elsewhere, simulated and actual employment and education levels compare well. With regard to the other outcomes - unemployment and NEA - the simulated and actual levels are also very similar throughout. From Table 4, we see that the simulations mostly do not differ significantly from the corresponding actual levels. The main exception to this is education, where in three of the five cases shown, the actual level lies outside the confidence interval of the simulated level (although not far outside in any case).

\footnotetext{
${ }^{12}$ Simulation in each month is carried out by dividing the unit interval into 4 sub-intervals according to the transition intensity for each possible destination from the current state (education, initially). The size of each sub-interval reflects the probability of exiting at that point to a particular destination (note that one of the destinations is the origin state, so "exits" to that state correspond to remaining in the origin state). We then generate a uniformly-distributed random number and decide the next state on the basis of which sub-interval this falls within.
} 
Figure 2: Actual (solid line) and simulated (dashed line) economic status, by month since reaching school-leaving age
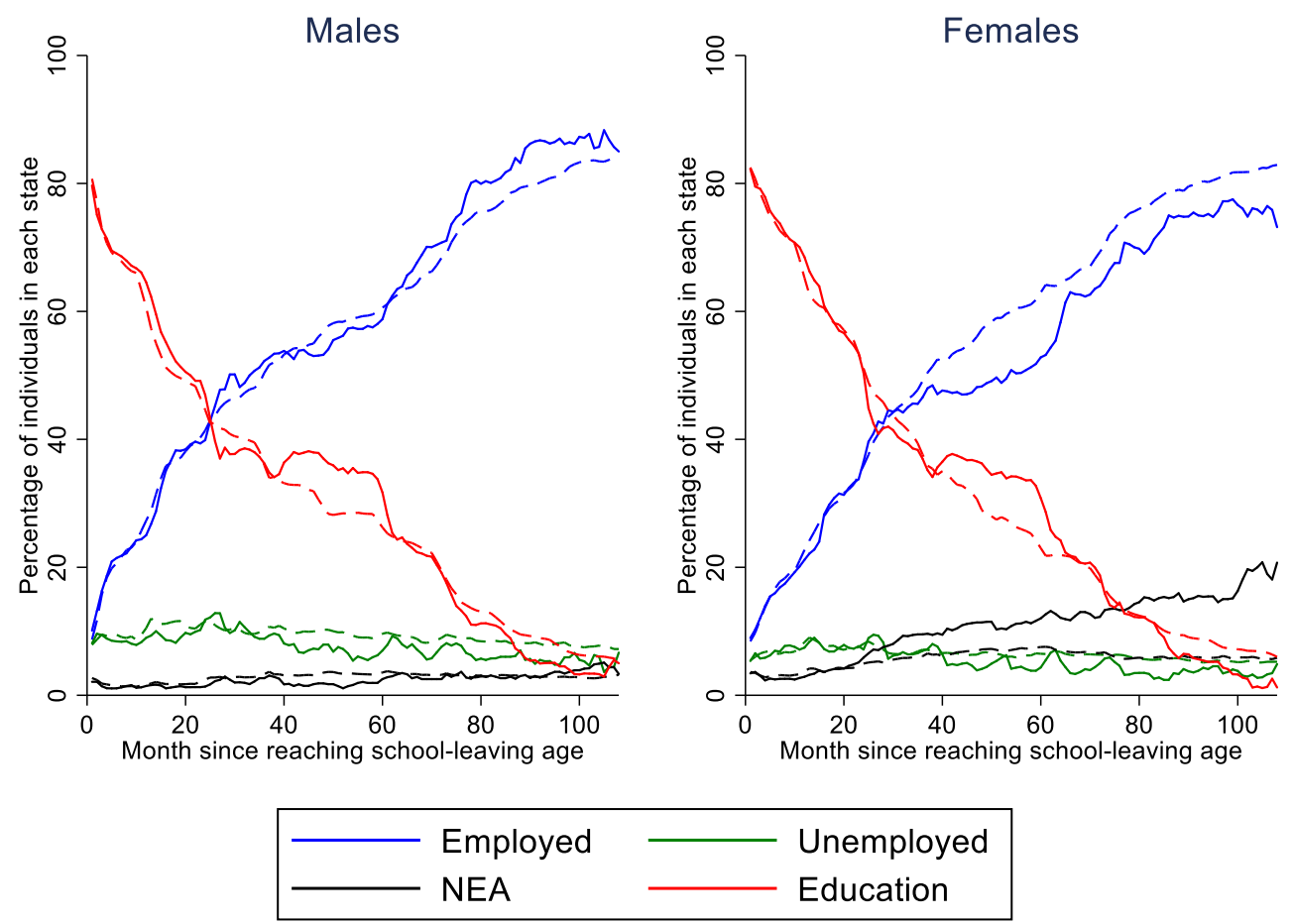

For females, the fit is visibly less close. The main challenge appears to be capturing the move into NEA; the actual levels by the end of the period are substantially above the simulated levels. This is likely to be due to becoming economically inactive after having children (something the model treats as exogenous). As with males, it is the case that the fit with regard to employment is less good during the typical higher education period than at other times. Nevertheless, Table 4 shows that actual levels of employment and unemployment are mostly not significantly different from simulated levels for the first five years. 
Table 4: Actual and simulated economic status, by year since reaching school-leaving age

\begin{tabular}{|c|c|c|c|c|c|c|c|c|}
\hline & Emp & & Unemp & & NEA & & Educ & \\
\hline Month: & Actual & Simulated & Actual & Simulated & Actual & Simulated & Actual & Simulated \\
\hline & \multicolumn{8}{|c|}{ Males } \\
\hline 12 & 0.25 & $\begin{array}{c}0.27 \\
(0.25,0.30)\end{array}$ & 0.09 & $\begin{array}{c}0.12 \\
(0.10,0.14)\end{array}$ & 0.02 & $\begin{array}{c}0.02 \\
(0.01,0.03)\end{array}$ & 0.57 & $\begin{array}{c}0.53 \\
(0.50,0.56)\end{array}$ \\
\hline 24 & 0.40 & $\begin{array}{c}0.42 \\
(0.39,0.45)\end{array}$ & 0.12 & $\begin{array}{c}0.11 \\
(0.09,0.14)\end{array}$ & 0.02 & $\begin{array}{c}0.03 \\
(0.02,0.04)\end{array}$ & 0.37 & $\begin{array}{c}0.42 \\
(0.38,0.46)\end{array}$ \\
\hline 36 & 0.52 & $\begin{array}{c}0.51 \\
(0.47,0.54)\end{array}$ & 0.09 & $\begin{array}{c}0.10 \\
(0.08,0.13)\end{array}$ & 0.03 & $\begin{array}{c}0.03 \\
(0.02,0.05)\end{array}$ & 0.35 & $\begin{array}{c}0.34 \\
(0.29,0.39)\end{array}$ \\
\hline 48 & 0.53 & $\begin{array}{c}0.57 \\
(0.53,0.61)\end{array}$ & 0.08 & $\begin{array}{c}0.10 \\
(0.08,0.13)\end{array}$ & 0.02 & $\begin{array}{c}0.04 \\
(0.02,0.05)\end{array}$ & 0.35 & $\begin{array}{c}0.29 \\
(0.24,0.33)\end{array}$ \\
\hline \multirow[t]{2}{*}{60} & 0.59 & $\begin{array}{c}0.61 \\
(0.57,0.65)\end{array}$ & 0.08 & $\begin{array}{c}0.09 \\
(0.07,0.12)\end{array}$ & 0.03 & $\begin{array}{c}0.04 \\
(0.02,0.05)\end{array}$ & 0.24 & $\begin{array}{c}0.25 \\
(0.21,0.29)\end{array}$ \\
\hline & \multicolumn{8}{|c|}{ Females } \\
\hline 12 & 0.21 & $\begin{array}{c}0.23 \\
(0.20,0.25)\end{array}$ & 0.08 & $\begin{array}{c}0.09 \\
(0.07,0.10)\end{array}$ & 0.03 & $\begin{array}{c}0.04 \\
(0.03,0.05)\end{array}$ & 0.64 & $\begin{array}{c}0.61 \\
(0.59,0.63)\end{array}$ \\
\hline 24 & 0.37 & $\begin{array}{c}0.36 \\
(0.33,0.39)\end{array}$ & 0.09 & $\begin{array}{c}0.08 \\
(0.07,0.10)\end{array}$ & 0.07 & $\begin{array}{c}0.05 \\
(0.04,0.07)\end{array}$ & 0.41 & $\begin{array}{c}0.47 \\
(0.44,0.50)\end{array}$ \\
\hline 36 & 0.47 & $\begin{array}{c}0.49 \\
(0.45,0.53)\end{array}$ & 0.07 & $\begin{array}{c}0.07 \\
(0.06,0.09)\end{array}$ & 0.09 & $\begin{array}{c}0.06 \\
(0.05,0.08)\end{array}$ & 0.36 & $\begin{array}{c}0.34 \\
(0.31,0.39)\end{array}$ \\
\hline 48 & 0.48 & $\begin{array}{c}0.57 \\
(0.53,0.61)\end{array}$ & 0.04 & $\begin{array}{c}0.07 \\
(0.05,0.08)\end{array}$ & 0.11 & $\begin{array}{c}0.07 \\
(0.06,0.09)\end{array}$ & 0.35 & $\begin{array}{c}0.27 \\
(0.24,0.32)\end{array}$ \\
\hline 60 & 0.53 & $\begin{array}{c}0.63 \\
(0.59,0.67)\end{array}$ & 0.05 & $\begin{array}{c}0.06 \\
(0.05,0.08)\end{array}$ & 0.13 & $\begin{array}{c}0.07 \\
(0.06,0.09)\end{array}$ & 0.25 & $\begin{array}{c}0.22 \\
(0.19,0.26)\end{array}$ \\
\hline
\end{tabular}

Simulations are based on 1,000 replications. The $2.5 \%-97.5 \%$ range of simulated levels are shown in parentheses.

Figure 3 presents the baseline transition intensities between all states as spell length increases up to 24 months. Since the model controls for unobserved heterogeneity, these estimates have a causal interpretation. For each type of transition, the intensity is expressed relative to that of the first month. This means that values greater than 1 imply positive duration dependence - the length of spell increasing the transition intensity - while values less than 1 imply negative duration dependence.

With this in mind, Figure 3 suggests negative duration dependence in the transitions from employment to unemployment. For transitions in the opposite direction, there is initially positive duration dependence but this fades over time, becoming negative for males after about a year. This is broadly consistent with Kalwij (2004) who finds negative duration dependence in young men's transitions into and out of unemployment in the UK. However, Figure 3 provides additional insight. While transitions from employment to all other 
destinations show negative duration dependence, transitions from unemployment to destinations other than employment do not. For males, this is consistent with Doiron and Gørgens' (2008) finding that constant baseline intensity cannot be rejected for youth transitions from unemployment to inactivity in Australia. The Kalwij (2004) finding of negative duration dependence in unemployment exits may reflect the fact that fact that the hazard rate is dominated by transitions into employment (due to them being more common than transitions to other states). Also apparent from Figure 3 are the marked differences between males and female, particularly in the transitions from unemployment to NEA.

For transitions from NEA, there is no comparable evidence in the literature. The relatively small number of transitions of this type in the data cautions against over-interpreting the impression of substantial gender differences given by Figure 3 (Tables A1a and A1b show a lack of statistical significance for the duration dependence coefficients terms relating to exits to employment and unemployment). Transitions from NEA to education do however show statistically significant negative duration dependence for both males and females.

Lastly, transitions intensities from education to all destinations fall substantially after the very start of the spell, beyond which there is little sign of duration dependence. This pattern is seen for both males and females. 


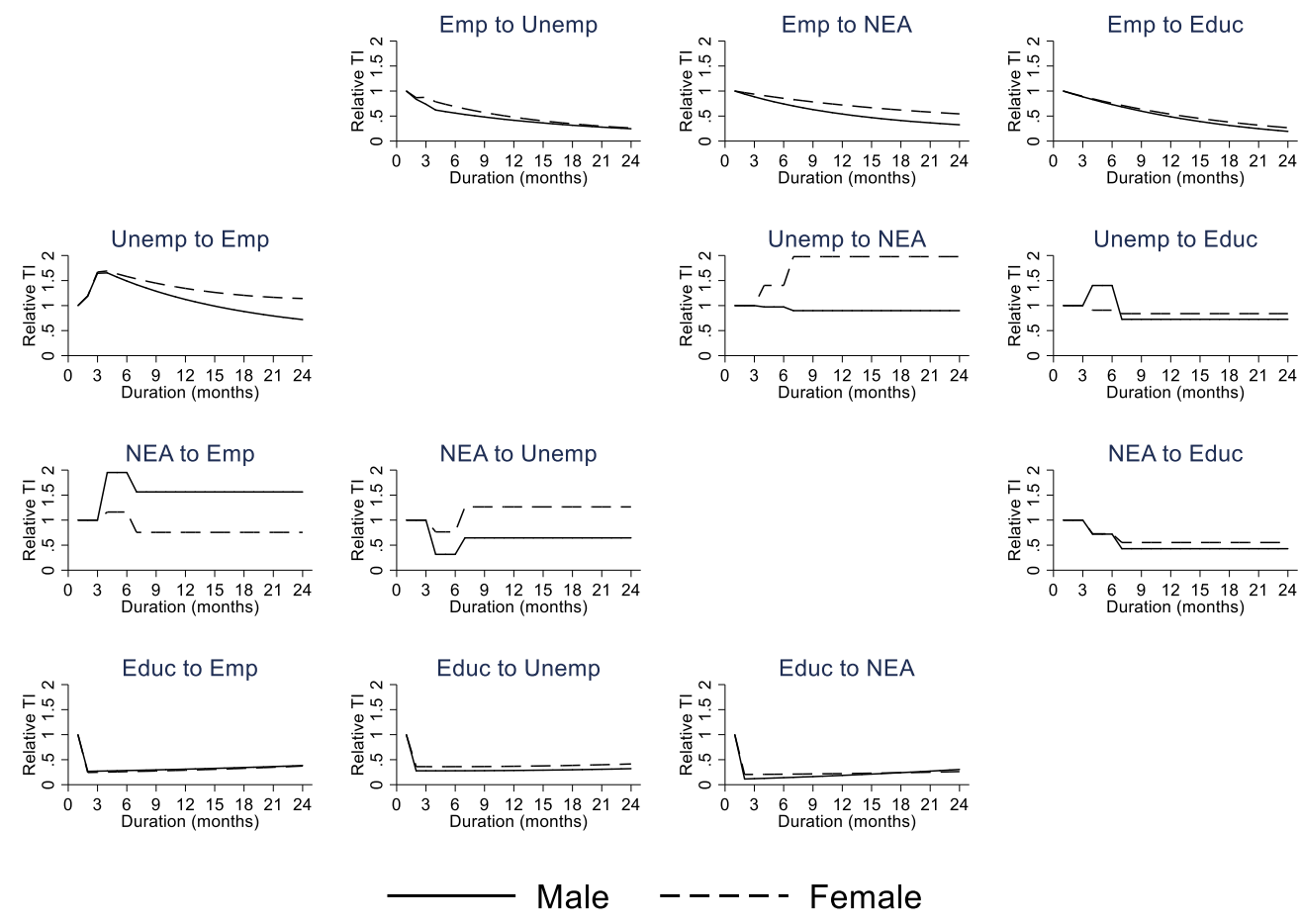

Note: Each chart shows the relative transition intensity, defined as the transition intensity from the origin state to the destination state as the length of time in the origin state increases, expressed relative to the its level in the first month.

Figure 3 illustrates the patterns of duration dependence but does not convey a sense of their magnitude. Figure 4 attempts to provides an intuitive impression of this. For each transition type it compares the proportionate (absolute) effect of being at a given point in the spell (rather than the start of the spell) to the proportionate (absolute) effect of having no qualifications at age 16 (rather than "good" qualifications, as represented by 5 or more GCSEs). A value of 1 at a particular duration therefore indicates that the effect of having spent that length of time in a particular state is similar in size (but not necessarily direction) to the effect of having no qualifications rather than good qualifications.

As a general comment, Figure 4 shows that the relative importance of duration dependence and qualification varies across transition types. With exits from employment, spell length reduces transition intensities but, for exits to unemployment, this impact is not as great as the difference between having no qualifications and having good qualifications. Looking at transitions from unemployment to employment, on the other hand, reveals a more complicated pattern. Here, the duration dependence effect is more important than the role of qualification in the early stages of the spell but this differential declines over time. 
Figure 4: Absolute duration dependence relative to the absolute effect of having no qualifications


Note: The lines in each chart trace out the ratio of the absolute factor by which duration in the origin state changes the intensity of transitions to the destination state above its month 1 level, relative to the absolute factor by which having no qualifications at age 16 (rather than 5 or more GCSEs) changes the transition intensity.

Table 5 presents the estimated lagged dependences. ${ }^{13}$ For males, the nature of the preceding spell and the length of that spell both significantly affect transitions from employment to unemployment. Relative to those entering work from education, having previously been unemployed nearly doubles this transition intensity (94 per cent increase). The effect is partially offset by the duration of the preceding spell. A 10 per cent increase in the length of the preceding unemployment spell reduces the transition intensity to unemployment by 1.75 per cent. ${ }^{14}$ This latter result may reflect improved matches among those taking longer in their search. However, the small size of the lagged duration effect relative to the effect of having previously been unemployed may suggest that for this age group it is in fact preferable to move into work quickly rather than to hold out for a better job offer. ${ }^{15}$ A similar pattern of

\footnotetext{
${ }^{13}$ Appendix A2 provides analogous results a) without controlling for unobserved heterogeneity and b) without controlling for unobserved heterogeneity or $X$.

${ }^{14}$ The lagged duration dependence coefficients are interpreted as the elasticities of the transition intensity with respect to the duration of the previous spell.

${ }^{15}$ Cockx and Picchio (2012) find a negative impact of prior unemployment duration on job-to-job transitions but not on employment exits. This implies that longer job search may achieve a better job match but that those in poor matches continue to search on the job and, through this, manage to stay in work.
} 
effects is evident for having previously been NEA. Here, however, lagged duration plays a more important role, with a 10 per cent increase in the length of the preceding NEA spell reducing the transition intensity to unemployment by 9.52 per cent. This means that having previously been NEA for more than 4 months reduces males' transition intensity from employment to unemployment.

Looking at males' transitions from unemployment, being employed prior to unemployment significantly increases the intensity of transitions back into work, relative to having previously been in education. The duration of the preceding employment spell is not important though. This may suggest that employers accept that young people may have only had short-term jobs and do not discriminate against them on that basis. It may also indicate that employers do attach much importance to the experience gained in previous employment amongst this age group. The role of having previously been NEA is interesting. A short prior NEA spell increases the probability of entering work. This may be capturing the fact that a transition from NEA to unemployment indicates a growing interest in finding work. However, the lagged duration dependence term acts such that prior NEA spells of 8 months or longer reduce the probability of entering employment.

Males' transitions from NEA show few significant effects of prior experience. Most significant is the effect of having been in work immediately before. This increases the probability of moving from NEA to unemployment.

For females, the pattern of results is rather different. Overall, prior experience seems to play a less important role in the transitions between employment and unemployment. As with males, having been unemployed immediately before being employed greatly increases the intensity of transitions back to unemployment, and this is offset by the duration of preceding unemployment (a 10 per cent increase reduces the intensity by 2.22 per cent). However, the effect of preceding NEA status and duration is not statistically significant. For unemployed females, the only significant impact is that being employed immediately before becoming unemployed increases the intensity of transitions into NEA relative to the baseline of having previously been in education. While it is difficult to interpret this finding, one speculation might be that it reflects females wishing to acquire some employment experience before having children. Lastly, turning to transitions from NEA, there is some evidence that the intensity of transitions into work are increased by having previously been employed. Having 
been unemployed immediately beforehand though reduces transition intensities to any destination (although not significantly so in the case of transitions to education). 
Table 5: The effect of prior status and lagged duration dependence in transition intensities between work ( $w$ ), unemployment (u), NEA ( $n$ ) and education (e), by sex

\begin{tabular}{|c|c|c|c|c|c|c|c|c|c|}
\hline & $w \rightarrow u$ & $w \rightarrow n$ & $w \rightarrow e$ & $u \rightarrow w$ & $u \rightarrow n$ & $u \rightarrow e$ & $\mathrm{n} \rightarrow \mathrm{w}$ & $\mathrm{n} \rightarrow \mathrm{u}$ & $\mathrm{n} \rightarrow \mathrm{e}$ \\
\hline & & & & & Males & & & & \\
\hline \multicolumn{10}{|l|}{ Preceding spell: } \\
\hline - Employed & & & & $0.46^{* * *}$ & -1.151 & 0.204 & 0.579 & $1.45^{* *}$ & 0.172 \\
\hline - Unemployed & $0.664 * * *$ & -0.021 & -0.077 & & & & 0.409 & -0.586 & -0.103 \\
\hline$-N E A$ & $1.138^{*}$ & -0.261 & -0.634 & $1.671^{* * *}$ & 1.034 & -0.172 & & & \\
\hline \multicolumn{10}{|c|}{ Lagged duration dependence (log months): } \\
\hline - Employed & & & & -0.009 & 0.213 & -0.262 & -0.121 & -0.38 & -0.232 \\
\hline - Unemployed & $-0.175^{* *}$ & -0.042 & $-0.593 * *$ & & & & $-0.763 *$ & 0.027 & -0.21 \\
\hline \multirow[t]{2}{*}{$-N E A$} & $-0.952 * *$ & 0.713 & 0.23 & $-0.842 * * *$ & -0.344 & 0.472 & & & \\
\hline & & & & & Females & & & & \\
\hline \multicolumn{10}{|l|}{ Preceding spell: } \\
\hline - Employed & & & & 0.165 & $0.904^{* *}$ & -0.023 & $0.553^{*}$ & 0.322 & 0.15 \\
\hline - Unemployed & $0.758 * * *$ & 0.018 & -0.52 & & & & $-1.018^{*}$ & $-1.434 * *$ & -0.536 \\
\hline$-N E A$ & 0.179 & 0.07 & -0.141 & -0.022 & -0.492 & -2.243 & & & \\
\hline \multicolumn{10}{|c|}{ Lagged duration dependence (log months): } \\
\hline - Employed & & & & 0.039 & -0.248 & -0.252 & $-0.202^{*}$ & -0.187 & -0.311 \\
\hline - Unemployed & $-0.222 *$ & 0.167 & -0.322 & & & & 0.216 & 0.445 & -0.461 \\
\hline$-N E A$ & -0.168 & 0.125 & -0.529 & -0.2 & 0.221 & 0.73 & & & \\
\hline
\end{tabular}


It is appropriate at this point to consider how these results relate to other empirical evidence. Most comparable is Kalwij (2004) who considers young males in the UK. Consistent with the results above, he finds a significant effect of prior unemployment on exits from unemployment but in contrast to our results, he finds that unemployment re-entry (loosely, employment exit) is not affected by the duration of the previous spell of unemployment. Looking at UK adults as a whole (rather than young people) this is also the finding of Böheim and Taylor (2002) and Tatsiramos (2009). Looking across studies of young people from other countries, the results of Cockx and Picchio (2013) find that lagged unemployment duration reduces the employment exit hazard (for men but not for women), Bratberg and Nilsen (2000) show a similar finding for Norway while Doiron and Gørgens (2008) find no such effect in the case of Australia.

Fewer studies examine the effect of employment experience. Böheim and Taylor (2002) provide marginally significant evidence that having more prior employment experience reduces the rate at which men return to unemployment but is not significant for women. Empirical evidence from other countries on the role of employment experience on young people's transitions is limited. For Belgium, Cockx and Picchio (2013) find marginally significant evidence of negative occurrence dependence in the employment exit hazard for young men. For young women they find strong evidence of negative lagged duration dependence in employment exits. For Australia, Doiron and Gørgens (2008), considering males and females together, find that the number of prior employment spells increases the intensity of transitions from unemployment into employment but that no other lagged dependences are significant.

As a general comment, differences in model parameterisation make it difficult to compare our results with other empirical studies. Where such comparison is possible, we see some consistent findings and some seeming inconsistencies. In the case of cross-country comparisons, this is perhaps not surprising given the institutional, cultural and economic differences.

To provide a sense of how the various effects interact to shape employment probabilities, Figure 4 provides a visualisation of three simulation exercises. Each exercise involves simulating outcomes after an initial period set to a specific state, repeating this with the initial period set to a different state, and then comparing the freely-simulated (i.e. after the fixed period) to provide an estimate of the relative impact of the two fixed experiences. 
To make this more concrete, the top two charts in Figure 5 compare simulated employment probabilities after spending the first 6 months post-school-leaving age unemployed with those after spending the first 6 months NEA. The relative impact of unemployment vs NEA by month since reaching school-leaving age is traced out by the line in each chart, with shaded areas depicting statistical significance. For both males and females, a clear difference is apparent. Relative to NEA, a 6-month period of unemployment significantly increases the probability of employment. This effect is substantial; Table 6 shows that 12 months after school-leaving age, the employment rate for males is 18.9 percentage points higher among the 6-month unemployed group than the 6-month NEA group. ${ }^{16}$ For females, the relative impact is 27.8 percentage points. Furthermore, these impacts appear long-lasting.

The middle charts relate to the case of 6 months' unemployment rather than 6 months NEA after having spent the first 6 months post-school in work. Hence, the first 12 months are set, and simulation only occurs beyond that point. This simulation exercise is intended to allow any positive effect of previous employment to shape future outcomes. In fact, the simulated relative impacts look very similar (just 6 months later) to those in the top row. Lastly, the charts in the bottom row show the results of varying the design of the simulation such that the period of unemployment or NEA lasts 12 months rather than 6 (again, after an initial 6-month period of employment). Once more, the results look very similar.

These results imply an important difference between unemployment and NEA. It would appear that economic inactivity (other than education) has more damaging long-term consequences than unemployment. The results confirm those of Flinn and Heckman (1983). Among the simulations considered, it is the occurrence rather than the duration of the out-ofwork spells that is important, and female outcomes are more sensitive than male.

\footnotetext{
${ }^{16}$ Also shown in Table 6 is the effect of unemployment or NEA relative to employment. From those results it is apparent that the positive effect of unemployment relative to NEA stems from unemployment being less harmful to employment relative to NEA rather than there being a positive effect of unemployment per se.
} 
Figure 5: Simulating the effect on employment probability of a spell of unemployment rather than a similar-length spell of NEA, by sex.
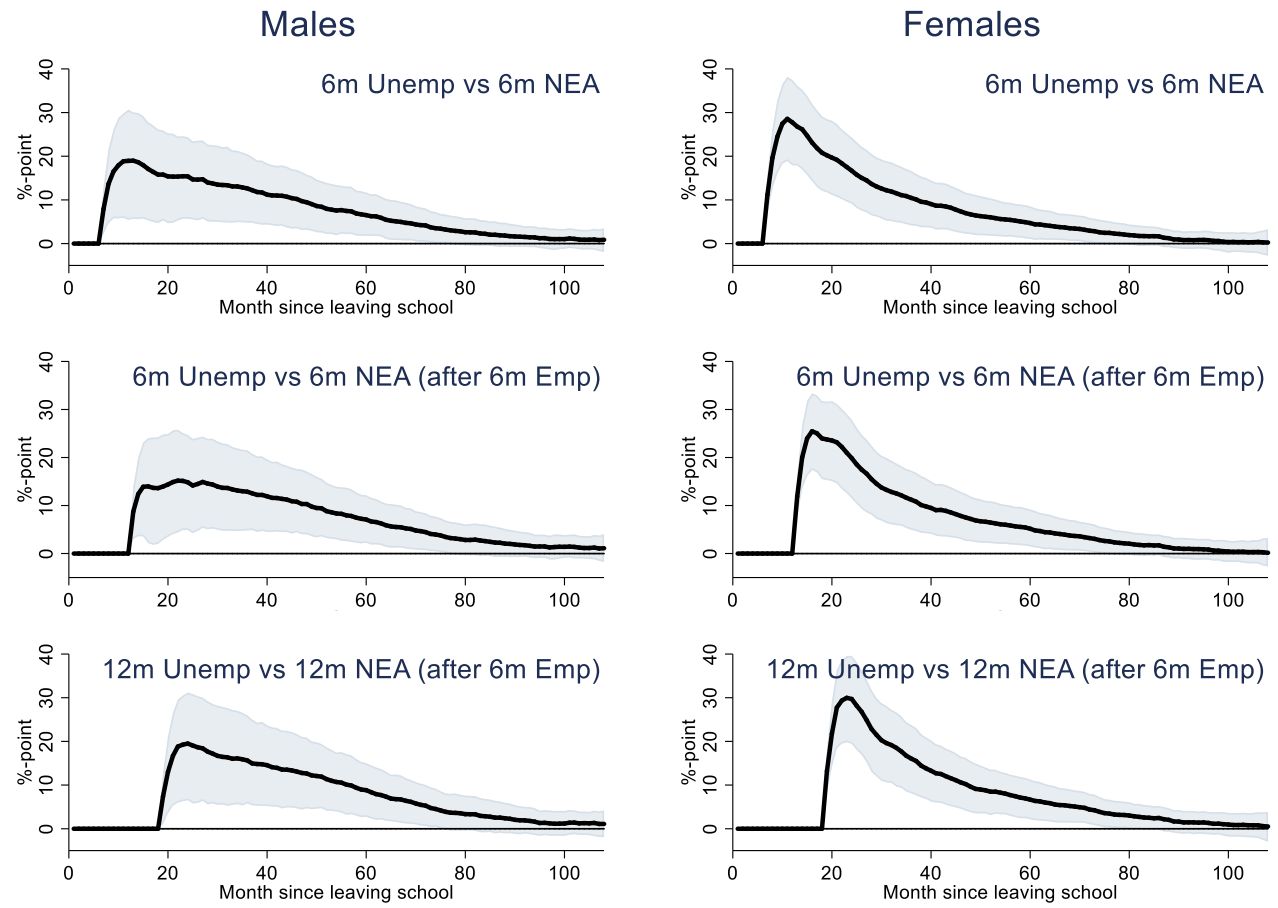

Note: The lines in each chart represent the simulated percentage-point differences in the impact on employment probability of previously experiencing unemployment rather than NEA. The top charts relate to the case of 6 months' unemployment rather than 6 months' NEA after leaving school. The middle charts relate to the case of 6 months' unemployment rather than $6^{\prime}$ months NEA after having spent the first 6 months postschool in work. The bottom charts relate to the case of 12 months' unemployment rather than 12 months' NEA after having spent the first 6 months post-school in work. Simulations are based on 1,000 replications and the shaded areas show the $2.5 \%-97.5 \%$ range of simulated impacts. 
Table 6: Simulating the (percentage point) effect on employment of prior unemployment compared to prior NEA after leaving school, by sex and month since reaching school-leaving age.




Note: This table shows, for selected months post school-leaving age: (1) the simulated percentage-point impact on employment probability of being unemployed rather than employed for the first 6 months (hence "U6 vs E6"); (2) the impact of the first 6 months NEA rather than employed and (3) shows the effect of the first 6 months unemployed rather than NEA. Columns 4-6 present analogous estimates, except now the 6-monthe employment, unemployment and NEA spells take place after an initial employment spell of 6 months ("E6U6 vs E6E6" in (4), for instance, refers to the effect of 6 months' employment then 6 months' unemployment relative to 6 months' employment followed by a further 6 months' employment). Columns 7-9 again impose an initial 6-month employment spell but then consider the impact of a subsequent employment, unemployment or NEA spell of 12 months. Columns 3, 6 and 9 correspond to the top, middle and bottom panels of Figure 5 , respectively. Simulations are based on 1,000 replications and the $2.5 \%-97.5 \%$ range of simulated impacts is shown beneath each estimate in parentheses. 
We turn finally to selected other interesting findings from the model. First, for both males and females, age is associated with reduced transitions from employment to unemployment and increased transitions from unemployment to employment (although the latter association is weaker). Combined, these findings are consistent with employment stability growing with age. This may reflect, in part, the effect of accumulated experience that has not been included in the model (due to a lack of formal identification results). It may also, however, reflect other factors such as improved job search technique and wider networks. Second, the results emphasise the key role of children for females' transitions. In particular, this strongly influences transitions from employment to NEA. Third, having poor (or no) qualifications increases the transition intensity from employment to unemployment and reduces transitions in the opposite direction for males and females alike. There does not appear to be an effect on transitions from NEA to employment for males, but for females such transitions have lower intensity among those with poor qualifications.

With regard to other age 16 characteristics, health affects males and females similarly, increasing the intensity of transitions from education to unemployment and, in particular, NEA. For those in work, the main effect is to increase the intensity of transitions to unemployment. Household income at age 16 shows no clear pattern. Higher parental qualifications are associated with slower exits from education, apart from male transitions into NEA. Interestingly, females with more educated parents have a lower intensity of transition from employment to unemployment but there is no such association for males. On the other hand, having an employed parent at age 16 is associated with a reduced intensity of the transition from employment to unemployment for males but this association is less strong for females.

We can also explore the effect of the business cycle. To do this, another simulation exercise was performed, this time manipulating the GDP variable so as to introduce a recession. Figure 6 shows the result of comparing means levels of each of the simulated outcomes to those arising from a baseline simulation with stable GDP growth. Each chart includes three vertical lines that correspond to the onset of the recession, the end of the recession and the point by which the economy had grown back to its pre-recession level. The recession was designed such that it begins 24 months after reaching school-leaving age and lasts 12 months, by which point the economy has contracted by $5 \%$. It then takes another 12 months for the economy to return to its pre-recession level. The four rows of charts show the simulated 
effects on the probabilities of employment, unemployment, NEA and education, respectively. Table 7 shows the results precisely, for every quarter from month 27 (the first quarter after the start of the recession) to month 60 (beyond which all impacts are non-significant).

The simulations clearly show the effect of the recession to be a reduction in employment and an increase in unemployment. For males, employment reduces by a maximum of 3.3 percentage points in month 36 (the simulated turning point for growth). For females, the employment impact continues to grow until month 39, by which point it is down 4.5 percentage points. The reduction in male employment is almost entirely accounted for by increased unemployment. Females on the other hand see the biggest increase in education. For both males and females, NEA rates are not affected by the simulated recession.

In addition to the size of the effects, males and females differ in the duration of their effects. The employment impact for males is rather short-lived, and not statistically significant beyond month 39. For females, the month 45 impact is still significant. On the other hand, the impact on male unemployment, as well as being bigger than for females, is longer-lasting.

Figure 6: Simulating the effect of a recession on the probabilities of employment, unemployment, NEA and Education, by sex
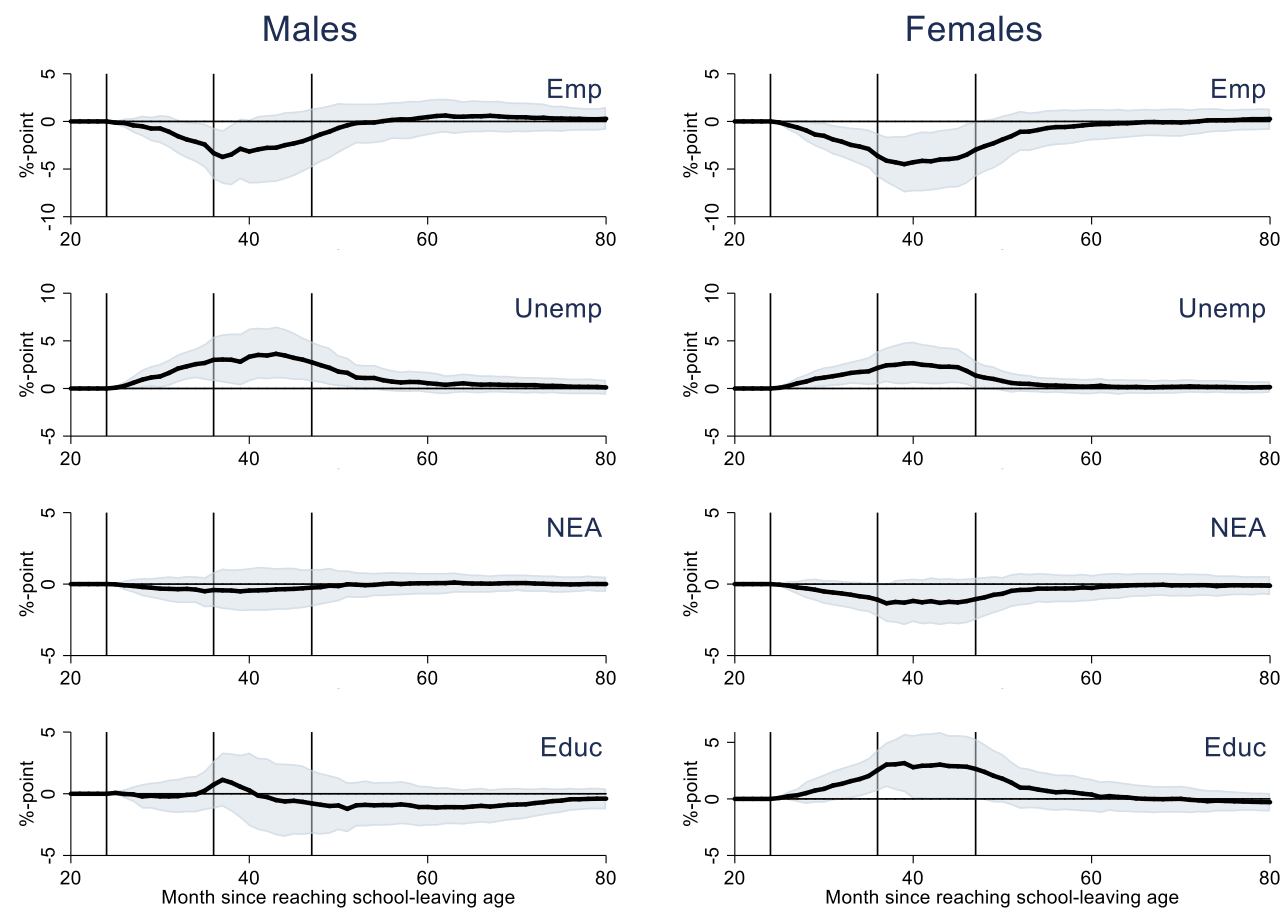

Note: The lines in each chart represent the simulated percentage-point impacts of a recession starting 24 months after reaching school-leaving age. The recession is designed to reduce the economy by $5 \%$ over the course of 12 months and then to take a further 12 months to return to the pre-recession level. Simulations are based on 1,000 replications and the shaded areas show the $2.5 \%-97.5 \%$ range of simulated impacts. 
Table 7: Simulating the (percentage point) impact of an economic downturn on the probabilities of employment, unemployment, NEA and education, by sex and month since reaching school-leaving age.

\begin{tabular}{|c|c|c|c|c|c|c|c|c|}
\hline \multirow[t]{2}{*}{ Month: } & \multicolumn{4}{|c|}{ Males } & \multicolumn{4}{|c|}{ Females } \\
\hline & Employment & Unemployment & NEA & Education & Employment & Unemployment & NEA & Education \\
\hline 27 & $(-1.2,0.4)$ & $(0.0,1.3)$ & $(-0.6,0.4)$ & $(-0.7,0.6)$ & $(-1.4,0.1)$ & $(0.0,1.2)$ & $(-0.7,0.2)$ & $(-0.3,0.9)$ \\
\hline 30 & $(-2.3,0.7)$ & $(0.1,2.6)$ & $(-1.1,0.5)$ & $(-1.4,1.0)$ & $(-3.0,-0.1)$ & $(0.2,2.2)$ & $(-1.4,0.3)$ & $(-0.3,2.2)$ \\
\hline \multirow[t]{2}{*}{33} & -1.9 & 2.3 & -0.3 & -0.1 & -2.5 & 1.6 & -0.7 & 1.6 \\
\hline & $(-3.9,0.0)$ & $(0.9,3.9)$ & $(-1.3,0.6)$ & $(-1.5,1.4)$ & $(-4.1,-0.7)$ & $(0.5,2.8)$ & $(-1.7,0.2)$ & $(0.1,3.0)$ \\
\hline \multirow[t]{2}{*}{39} & -2.9 & 2.8 & -0.5 & 0.6 & -4.5 & 2.6 & -1.3 & 3.2 \\
\hline & $(-6.1,0.3)$ & $(0.3,5.7)$ & $(-1.9,1.1)$ & $(-2.0,3.2)$ & $(-7.5,-1.5)$ & $(0.4,4.8)$ & $(-2.9,0.3)$ & $(0.6,5.7)$ \\
\hline \multirow[t]{2}{*}{42} & -2.8 & 3.5 & -0.4 & -0.3 & -4.2 & 2.4 & -1.2 & 3.0 \\
\hline & $(-6.4,0.7)$ & $(1.0,6.3)$ & $(-1.9,1.2)$ & $(-3.1,2.9)$ & $(-7.3,-1.1)$ & $(0.4,4.6)$ & $(-2.8,0.5)$ & $(-0.1,5.8)$ \\
\hline \multirow[t]{2}{*}{45} & -2.3 & 3.2 & -0.3 & -0.6 & -3.8 & 2.2 & -1.3 & 2.9 \\
\hline & $(-5.7,1.0)$ & $(0.9,5.9)$ & $(-1.7,1.1)$ & $(-3.3,2.4)$ & $(-6.9,-0.7)$ & $(0.6,4.2)$ & $(-2.8,0.4)$ & $(0.0,5.6)$ \\
\hline 51 & $(-2.8,1.9)$ & $(0.2,3.2)$ & $(-0.9,1.0)$ & $(-3.1,0.9)$ & $(-3.6,0.8)$ & $(-0.4,1.7)$ & $(-1.6,0.7)$ & $(-0.6,3.3)$ \\
\hline \multirow[t]{2}{*}{54} & -0.1 & 1.1 & -0.1 & -0.9 & -0.9 & 0.4 & -0.3 & 0.8 \\
\hline & $(-2.3,1.9)$ & $(-0.1,2.5)$ & $(-0.8,0.8)$ & $(-2.6,0.9)$ & $(-2.9,1.0)$ & $(-0.4,1.2)$ & $(-1.3,0.8)$ & $(-0.9,2.4)$ \\
\hline \multirow[t]{2}{*}{57} & 0.2 & 0.6 & 0.0 & -0.9 & -0.6 & 0.3 & -0.3 & 0.6 \\
\hline & $(-1.9,2.0)$ & $(-0.4,1.8)$ & $(-0.8,0.8)$ & $(-2.5,1.0)$ & $(-2.4,1.3)$ & $(-0.5,1.0)$ & $(-1.3,0.7)$ & $(-1.0,2.2)$ \\
\hline \multirow[t]{2}{*}{60} & 0.5 & 0.6 & 0.1 & -1.1 & -0.3 & 0.2 & -0.3 & 0.4 \\
\hline & $(-1.4,2.3)$ & $(-0.5,1.7)$ & $(-0.7,0.8)$ & $(-2.6,0.6)$ & $(-2 \cdot 0,1.3)$ & $(-0.6,1.0)$ & $(-1.2,0.6)$ & $(-1.1,1.8)$ \\
\hline
\end{tabular}


Note: This table shows, for selected months post school-leaving age, the impact of a recession commencing 24 months post-school leaving age, contracting the economy by $5 \%$ over the course of 12 months and then requiring a further 12 months before the pre-recession level is restored. It corresponds to the results visualised in Figure 6 . Simulations are based on 1,000 replications and the $2.5 \%-97.5 \%$ range of simulated impacts is shown beneath each estimate in parentheses. 


\section{Conclusion}

This paper has examined labour market transitions among young people in the UK from the point of school-leaving age onwards. Using an econometric model of transitions that allows for the influence of unobserved heterogeneity, we have been able to identify the effect of prior spells on current transitions. We look beyond transitions into and out of employment by considering four potential states - employment, unemployment, NEA and education. This provides a fuller characterisation of the typical activities relevant to young people than allowed for by other studies. We provide rich evidence on the effect of experience on subsequent outcomes, providing an insight into the scarring literature which typically relates adult outcomes to experiences when younger. Furthermore, we provide new evidence on duration dependence, which we allow to vary by transition type.

The results show the importance of distinguishing between unemployment and NEA status. The latter is shown to have a more damaging long-term impact on the probability of entering work. This is true for both males and females. An implication is that policy-makers should focus not just on those young people engaged in job search but should also intervene to prevent young people becoming disengaged from the labour market. Compounding this, the results show the positive impact of employment experience for males; programmes that can provide work experience therefore have the potential to improve young men's resilience in the labour market. For females, however, prior employment appears less important. NEA features more prominently among females than males, with motherhood being the key factor behind this. 


\section{References}

Abbring, J. and van den Berg, G. (2003), 'The identifiability of the mixed proportional hazards competing risks model', Journal of the Royal Statistical Society: Series B (Statistical Methodology) 65(3), 701-710.

Arulampalam, W. (2001), 'Is unemployment really scarring? effects of unemployment experiences on wages', The Economic Journal 111(475), 585-606.

Arulampalam, W., Booth, A. and Taylor, M. (2000), 'Unemployment persistence', Oxford Economic Papers 52(1), 24-50.

van den Berg, G. J. (2001), 'Duration models: specification, identification and multiple durations', Handbook of econometrics 5, 3381-3460.

van den Berg, G. J., Bergemann, A. H. and Caliendo, M. (2009), 'The effect of active labor market programs on not-yet treated unemployed individuals', Journal of the European Economic Association 7(2-3), 606-616.

van den Berg, G. J., van der Klaauw, B. (2001) 'Combining micro and macro unemployment duration data' Journal of Econometrics 102 (2), 271-309.

van den Berg, G. and Lindeboom, M. (1998), 'Attrition in panel survey data and the estimation of multi-state labor market models', Journal of Human Resources pp. 458-478.

Blanchard, O. and Diamond, P. (1994), 'Ranking, unemployment duration, and wages', The Review of Economic Studies 61(3), 417-434.

Böheim, R. and Taylor, M. P. (2002), 'The search for success: do the unemployed find stable employment?’. Labour Economics 9(6), 717-735.

Bonnal L., Fougere D., and Serandon S. (1997). 'Evaluating the Impact of French Employment Policies on Individual Labour Market Histories'. Review of Economic Studies, 64(4): 683-713.

Bratberg E. and Nilsen O. (2000). "Transitions from School to Work and the Early Labour Market Experience.” Oxford Bulletin of Economics and Statistics, 62(s1): 909-929.

Brinch, C. (2011), 'Non-parametric identification of the mixed proportional hazards model with interval-censored durations', The Econometrics Journal 14(2), 343-350.

Burgess, S., Propper, C., Rees, H. and Shearer, A. (2003), 'The class of 1981: the effects of early career unemployment on subsequent unemployment experiences', Labour Economics 10(3), 291-309.

Cai, L., Mavromaras, K and Sloane, P. (2018) 'Low Paid Employment in Britain: Estimating State-Dependence and Stepping Stone Effects' Oxford Bulletin of Economics and Statistics 80(2), 283-326 
Calvo-Armengol, A. and Jackson, M. (2004), 'The effects of social networks on employment and inequality', The American Economic Review 94(3), 426-454.

Cappellari, L. and Jenkins, S. (2004), 'Modelling low income transitions', Journal of Applied Econometrics 19(5), 593-610.

Cockx, B. and Picchio, M. (2012), 'Are short-lived jobs stepping stones to long-lasting jobs?', Oxford Bulletin of Economics and Statistics 74(5), 646-675.

Cockx, B. and Picchio, M. (2013), 'Scarring effects of remaining unemployed for long-term unemployed school-leavers', Journal of the Royal Statistical Society: Series A (Statistics in Society) 176(4), 951-980.

Coviello, V. and Boggess, M. (2004), 'Cumulative incidence estimation in the presence of competing risks', Stata journal 4, 103-112.

Doiron, D. and Gørgens, T. (2008), 'State dependence in youth labor market experiences, and the evaluation of policy interventions', Journal of Econometrics 145(1-2), 81-97.

Dorsett, R. and Lucchino, P. (2014) Explaining patterns in the school-to-work transition: an analysis using optimal matching. Advances in Life Course Research 22: 1-14.

Eberwein, C., Ham, J. and Lalonde, R. (1997). "The Impact of Classroom Training on the Employment Histories of Disadvantaged Women: Evidence from Experimental Data." Review of Economic Studies 64(4): 655-682

Flinn, C., and Heckman, J. (1983), 'Are Unemployment and Out of the Labor Force Behaviorally Distinct Labor Force States?’ Journal of Labor Economics 1: 28-42.

Frijters, P. (2002), 'The non-parametric identification of lagged duration dependence', Economics Letters 75(3), 289-292.

Gaure, S., Røed, K. and Zhang, T. (2007), 'Time and causality: A Monte Carlo assessment of the timing-of-events approach', Journal of Econometrics 141(2), 1159-1195.

Geerdsen, L. P. (2006), 'Is there a threat effect of labour market programmes? A study of ALMP in the Danish UI system', The Economic Journal 116(513), 738-750.

Gregg, P. (2001), 'The impact of youth unemployment on adult unemployment in the NCDS', The Economic Journal 111(475), 626-653.

Gregg, P. and Tominey, E. (2005), 'The wage scar from male youth unemployment', Labour Economics 12(4), $487-509$.

Heckman, J. (1981), The incidental parameters problem and the problem of initial conditions in estimating a discrete time-discrete data stochastic process, in C. Manski and D. McFadden, eds, 'Structural Analysis of Discrete Data With Economic Applications', The MIT Press, pp. 343-350. 
Heckman, J. and Borjas, G. (1980), 'Does unemployment cause future unemployment? definitions, questions and answers from a continuous time model of heterogeneity and state dependence', Economica 47(187), 247-283.

Heckman, J. and Singer, B. (1984), 'A method for minimizing the impact of distributional assumptions in econometric models for duration data', Econometrica pp. 271-320.

Honoré, B. (1993), 'Identification results for duration models with multiple spells', The Review of Economic Studies 60(1), 241.

Horny, G. and Picchio, M. (2010), 'Identification of lagged duration dependence in multiplespell competing risks models', Economics Letters 106(3), 241-243.

Jones, S. and Riddell, W. (2006). 'Unemployment and Nonemployment: Heterogeneities in Labor Market States', The Review of Economics and Statistics, 88(2): 314-323.

Kalwij, A. (2004), 'Unemployment experiences of young men: on the road to stable employment?’, Oxford Bulletin of Economics and Statistics 66(2), 205-237.

Kiefer, N. and Neumann, G. (1989), 'Search models and applied labor economics'.

Lancaster, T. (1979), 'Econometric methods for the duration of unemployment', Econometrica pp. 939-956.

Lockwood, B. (1991), 'Information externalities in the labour market and the duration of unemployment', The Review of Economic Studies 58(4), 733-753.

Maré, D. (2006), 'Constructing consistent work-life histories: a guide for users of the British Household Panel Survey’, ISER Working Paper Series.

Mitchell, J., Smith, R., Weale, M., Wright, S. and Salazar, E. (2005), 'An indicator of monthly GDP and an early estimate of quarterly GDP growth', The Economic Journal 115(501), F108-F129.

Mroz, T. and Savage T.H. (2006). "The Long-Term Effects of Youth Unemployment." Journal of Human Resources, 41(2): 259-293.

Paull, G. (2002), 'Biases in the reporting of labour market dynamics', IFS Working Papers.

Pissarides, C. (1992), 'Loss of skill during unemployment and the persistence of employment shocks', The Quarterly Journal of Economics 107(4), 1371-1391.

Røed, K. and Raaum, O. (2006), 'Do labour market programmes speed up the return to work?', Oxford Bulletin of Economics and Statistics 68(5), 541-568.

Stewart, M. B. (2007), 'The interrelated dynamics of unemployment and low-wage employment', Journal of Applied Econometrics 22(3), 511-531. 
Tatsiramos, K. (2009), 'Unemployment insurance in Europe: Unemployment duration and subsequent employment stability', Journal of the European Economic Association 7(6), 1225-1260.

Vishwanath, T. (1989), 'Job search, stigma effect, and escape rate from unemployment', Journal of Labor Economics pp. 487-502. 


\section{Appendix A1 - full results}

Table A1a: Full estimation results showing transitions between work (w), unemployment (u), NEA ( $n$ ) and education (e) for males

\begin{tabular}{|c|c|c|c|c|c|c|c|c|c|c|c|c|}
\hline & $w \rightarrow u$ & $w \rightarrow n$ & $w \rightarrow e$ & $u \rightarrow w$ & $u \rightarrow n$ & $u \rightarrow e$ & $n \rightarrow w$ & $\mathrm{n} \rightarrow \mathrm{u}$ & $\mathrm{n} \rightarrow \mathrm{e}$ & $e \rightarrow w$ & $\mathrm{e} \rightarrow \mathrm{u}$ & $\mathrm{e} \rightarrow \mathrm{n}$ \\
\hline \multicolumn{13}{|l|}{ Baseline hazard: } \\
\hline \multirow[t]{2}{*}{ - month 1} & 0.316 & & & -0.666 & & & & & & 1.332 & 1.276 & 2.216 \\
\hline & $(0.137)$ & & & $(0.147)$ & & & & & & (0.108) & $(0.149)$ & $(0.335)$ \\
\hline \multirow[t]{2}{*}{ - month 2} & 0.191 & & & -0.435 & & & & & & & & \\
\hline & $(0.146)$ & & & $(0.134)$ & & & & & & & & \\
\hline \multirow[t]{2}{*}{ - month 3} & 0.119 & & & -0.058 & & & & & & & & \\
\hline & $(0.154)$ & & & $(0.121)$ & & & & & & & & \\
\hline \multirow[t]{2}{*}{ - months 1-3 } & & & & & 0.107 & 0.32 & -0.447 & 0.438 & 0.847 & & & \\
\hline & & & & & $(0.357)$ & $(0.310)$ & $(0.285)$ & $(0.404)$ & $(0.324)$ & & & \\
\hline \multirow[t]{2}{*}{ - months 4-6 } & & & & & 0.08 & 0.658 & 0.222 & -0.71 & 0.519 & & & \\
\hline & & & & & $(0.442)$ & $(0.337)$ & $(0.296)$ & $(0.602)$ & $(0.435)$ & & & \\
\hline \multirow[t]{2}{*}{ - (standardised) duration } & -1.106 & -1.276 & -1.188 & -1.146 & & & & & & 0.271 & -0.047 & 1.065 \\
\hline & $(0.198)$ & $(0.302)$ & $(0.343)$ & $(0.296)$ & & & & & & $(0.129)$ & $(0.200)$ & $(0.400)$ \\
\hline \multirow[t]{2}{*}{ - (standardised) duration squared } & 0.502 & 0.927 & -0.721 & 0.861 & & & & & & 0.161 & 0.516 & -0.523 \\
\hline & $(0.207)$ & $(0.286)$ & $(0.737)$ & $(0.401)$ & & & & & & $(0.133)$ & $(0.206)$ & $(0.413)$ \\
\hline \multicolumn{13}{|l|}{ Preceding spell: } \\
\hline & & & & 0.46 & -1.151 & 0.204 & 0.579 & 1.45 & 0.172 & & & \\
\hline & & & & $(0.144)$ & $(0.720)$ & $(0.430)$ & $(0.407)$ & $(0.683)$ & $(0.648)$ & & & \\
\hline \multirow{2}{*}{ - Unemployed } & 0.664 & -0.021 & -0.077 & & & & 0.409 & -0.586 & -0.103 & & & \\
\hline & $(0.182)$ & $(0.489)$ & $(0.414)$ & & & & $(0.810)$ & $(0.945)$ & $(1.244)$ & & & \\
\hline \multirow[t]{2}{*}{$-N E A$} & 1.138 & -0.261 & -0.634 & 1.671 & 1.034 & -0.172 & & & & & & \\
\hline & $(0.654)$ & $(0.899)$ & $(0.774)$ & $(0.453)$ & (1.237) & $(1.202)$ & & & & & & \\
\hline \multicolumn{13}{|l|}{$\begin{array}{l}\text { Lagged duration dependence } \\
\text { (log months): }\end{array}$} \\
\hline \multirow[t]{2}{*}{ - Employed } & & & & -0.009 & 0.213 & -0.262 & -0.121 & -0.38 & -0.232 & & & \\
\hline & & & & $(0.058)$ & $(0.309)$ & $(0.213)$ & $(0.143)$ & $(0.275)$ & $(0.314)$ & & & \\
\hline - Unemployed & -0.175 & -0.042 & -0.593 & & & & -0.763 & 0.027 & -0.21 & & & \\
\hline
\end{tabular}




\begin{tabular}{|c|c|c|c|c|c|c|c|c|c|c|c|c|}
\hline & $(0.085)$ & $(0.286)$ & $(0.269)$ & & & & $(0.442)$ & $(0.407)$ & $(0.668)$ & & & \\
\hline \multirow[t]{2}{*}{$-N E A$} & -0.952 & 0.713 & 0.23 & -0.842 & -0.344 & 0.472 & & & & & & \\
\hline & $(0.423)$ & $(0.456)$ & $(0.445)$ & $(0.279)$ & $(0.521)$ & $(0.559)$ & & & & & & \\
\hline \multicolumn{13}{|l|}{ Age } \\
\hline \multirow[t]{2}{*}{$-18-21$} & -0.198 & 0.186 & 0.457 & 0.111 & 0.89 & -0.373 & -0.072 & 0.073 & 0.05 & 0.104 & -0.084 & 0.451 \\
\hline & $(0.095)$ & $(0.217)$ & $(0.136)$ & $(0.085)$ & $(0.367)$ & $(0.242)$ & $(0.228)$ & $(0.356)$ & $(0.270)$ & $(0.124)$ & $(0.224)$ & $(0.284)$ \\
\hline \multirow[t]{2}{*}{-22 or over } & -0.356 & -0.136 & -1.225 & 0.312 & -0.217 & -0.855 & 0.382 & 0.174 & -1.646 & 0.637 & 0.724 & -0.422 \\
\hline & $(0.134)$ & $(0.289)$ & $(0.243)$ & $(0.108)$ & $(0.453)$ & $(0.382)$ & $(0.275)$ & $(0.513)$ & $(0.482)$ & $(0.221)$ & $(0.373)$ & $(1.027)$ \\
\hline \multicolumn{13}{|l|}{ Qualification at age 16: } \\
\hline \multirow[t]{2}{*}{ - Fewer than 5 A-C GCSES } & 0.081 & -0.424 & -0.665 & 0.079 & -0.29 & 0.024 & 0.654 & 0.415 & -0.884 & 0.764 & 0.828 & -0.125 \\
\hline & $(0.129)$ & $(0.257)$ & $(0.160)$ & $(0.108)$ & $(0.483)$ & $(0.255)$ & $(0.317)$ & (0.559) & $(0.393)$ & $(0.091)$ & (0.139) & $(0.263)$ \\
\hline \multirow[t]{2}{*}{ - CSE } & 0.42 & -0.413 & -0.886 & 0.069 & 0.681 & -0.367 & 0.659 & 1.518 & -1.126 & 1.054 & 1.394 & 0.753 \\
\hline & $(0.141)$ & (0.339) & $(0.233)$ & $(0.121)$ & $(0.477)$ & $(0.315)$ & $(0.413)$ & $(0.590)$ & $(0.472)$ & $(0.129)$ & $(0.182)$ & (0.313) \\
\hline \multirow[t]{2}{*}{ - none } & 0.731 & 0.388 & -0.881 & -0.442 & -0.342 & -0.947 & 0.42 & 2.321 & -2.042 & 0.809 & 1.297 & 0.585 \\
\hline & $(0.161)$ & $(0.326)$ & $(0.295)$ & $(0.144)$ & $(0.570)$ & $(0.397)$ & $(0.548)$ & $(0.723)$ & $(0.617)$ & $(0.147)$ & $(0.208)$ & $(0.365)$ \\
\hline \multirow[t]{2}{*}{ Health problem, age 16} & 0.392 & -0.085 & 0.094 & -0.009 & 0.036 & -0.339 & 0.149 & -0.301 & 0.103 & -0.065 & 0.467 & 0.639 \\
\hline & $(0.107)$ & $(0.270)$ & $(0.167)$ & $(0.093)$ & $(0.382)$ & $(0.254)$ & (0.269) & $(0.418)$ & $(0.310)$ & $(0.101)$ & (0.129) & $(0.217)$ \\
\hline \multicolumn{13}{|l|}{ Household income, age 16} \\
\hline \multirow[t]{2}{*}{ - quartile 1 (lowest) } & 0.203 & -0.104 & -0.122 & -0.194 & -0.367 & -0.216 & -0.444 & -0.84 & 0.282 & 0.036 & 0.679 & 0.603 \\
\hline & $(0.171)$ & $(0.370)$ & $(0.219)$ & $(0.148)$ & $(0.609)$ & $(0.389)$ & $(0.402)$ & $(0.651)$ & $(0.425)$ & $(0.130)$ & $(0.206)$ & $(0.335)$ \\
\hline \multirow[t]{2}{*}{ - quartile 2} & -0.222 & -0.049 & -0.015 & -0.116 & -0.226 & -0.074 & -0.068 & -0.869 & -0.311 & -0.006 & 0.395 & 0.245 \\
\hline & $(0.165)$ & $(0.328)$ & $(0.183)$ & $(0.145)$ & $(0.593)$ & $(0.374)$ & (0.395) & (0.634) & $(0.448)$ & $(0.115)$ & (0.199) & $(0.314)$ \\
\hline \multirow[t]{2}{*}{ - quartile 3} & -0.054 & 0.046 & -0.196 & 0.103 & 0.055 & 0.144 & -0.078 & 0.007 & 0.157 & 0.066 & 0.517 & 0.357 \\
\hline & $(0.157)$ & $(0.305)$ & $(0.176)$ & $(0.142)$ & $(0.598)$ & $(0.359)$ & $(0.345)$ & (0.619) & $(0.375)$ & $(0.110)$ & (0.195) & $(0.292)$ \\
\hline \multicolumn{13}{|c|}{ Parent's highest qualification: } \\
\hline \multirow[t]{2}{*}{ - NVQ1 } & -0.122 & 0.041 & 0.31 & -0.158 & -0.283 & -0.151 & 0.3 & -0.657 & 0.228 & -0.153 & -0.204 & 0.343 \\
\hline & $(0.134)$ & $(0.347)$ & $(0.255)$ & $(0.118)$ & $(0.452)$ & $(0.301)$ & $(0.527)$ & (0.695) & $(0.494)$ & $(0.119)$ & $(0.155)$ & $(0.359)$ \\
\hline \multirow[t]{2}{*}{ - NVQ2 } & -0.049 & 0.265 & 0.744 & 0.134 & 0.696 & 0.099 & 0.389 & -0.828 & 0.335 & -0.022 & -0.202 & 0.574 \\
\hline & $(0.178)$ & $(0.424)$ & $(0.282)$ & $(0.159)$ & $(0.521)$ & $(0.444)$ & $(0.592)$ & $(0.681)$ & $(0.619)$ & $(0.147)$ & $(0.227)$ & $(0.434)$ \\
\hline \multirow[t]{2}{*}{ - NVQ3 } & -0.28 & 0.486 & 0.626 & 0.168 & -0.727 & 0.534 & 0.847 & -0.566 & 0.263 & -0.302 & -0.429 & 0.616 \\
\hline & $(0.179)$ & $(0.396)$ & $(0.283)$ & $(0.156)$ & $(0.823)$ & $(0.382)$ & $(0.591)$ & $(0.853)$ & $(0.573)$ & (0.139) & (0.197) & (0.395) \\
\hline
\end{tabular}




\begin{tabular}{|c|c|c|c|c|c|c|c|c|c|c|c|c|}
\hline$-N V Q 4$ & $\begin{array}{c}-0.102 \\
(0.169)\end{array}$ & $\begin{array}{c}0.53 \\
(0.381)\end{array}$ & $\begin{array}{l}1.129 \\
(0.260)\end{array}$ & $\begin{array}{c}0.133 \\
(0.149)\end{array}$ & $\begin{array}{c}0.23 \\
(0.606)\end{array}$ & $\begin{array}{c}0.675 \\
(0.355)\end{array}$ & $\begin{array}{c}0.578 \\
(0.572)\end{array}$ & $\begin{array}{l}-1.567 \\
(0.902)\end{array}$ & $\begin{array}{c}0.213 \\
(0.508)\end{array}$ & $\begin{array}{c}-0.603 \\
(0.135)\end{array}$ & $\begin{array}{c}-0.83 \\
(0.190)\end{array}$ & $\begin{array}{c}0.35 \\
(0.376)\end{array}$ \\
\hline At age 16, parent working & $\begin{array}{l}-0.455 \\
(0.146)\end{array}$ & $\begin{array}{l}-0.431 \\
(0.349)\end{array}$ & $\begin{array}{c}0.017 \\
(0.236)\end{array}$ & $\begin{array}{l}0.198 \\
(0.121)\end{array}$ & $\begin{array}{l}-0.632 \\
(0.450)\end{array}$ & $\begin{array}{l}0.057 \\
(0.312)\end{array}$ & $\begin{array}{c}0.082 \\
(0.510)\end{array}$ & $\begin{array}{c}0.75 \\
(0.709)\end{array}$ & $\begin{array}{c}0.007 \\
(0.426)\end{array}$ & $\begin{array}{c}0.245 \\
(0.122)\end{array}$ & $\begin{array}{l}-0.232 \\
(0.157)\end{array}$ & $\begin{array}{l}-0.314 \\
(0.292)\end{array}$ \\
\hline \multicolumn{13}{|l|}{ Season: } \\
\hline - January - March & $\begin{array}{l}-0.339 \\
(0.120)\end{array}$ & $\begin{array}{c}0.21 \\
(0.325)\end{array}$ & $\begin{array}{l}-1.468 \\
(0.317)\end{array}$ & $\begin{array}{l}-0.121 \\
(0.110)\end{array}$ & $\begin{array}{l}-0.984 \\
(0.586)\end{array}$ & $\begin{array}{l}-1.89 \\
(0.619)\end{array}$ & $\begin{array}{l}-0.689 \\
(0.346)\end{array}$ & $\begin{array}{c}0.521 \\
(0.569)\end{array}$ & $\begin{array}{c}1.118 \\
(0.853)\end{array}$ & $\begin{array}{l}-0.717 \\
(0.157)\end{array}$ & $\begin{array}{l}-0.297 \\
(0.251)\end{array}$ & $\begin{array}{l}-0.413 \\
(0.518)\end{array}$ \\
\hline - April - May & $\begin{array}{l}-0.193 \\
(0.116)\end{array}$ & $\begin{array}{c}0.125 \\
(0.340)\end{array}$ & $\begin{array}{l}-2.018 \\
(0.430)\end{array}$ & $\begin{array}{l}-0.105 \\
(0.112)\end{array}$ & $\begin{array}{l}-0.738 \\
(0.544)\end{array}$ & $\begin{array}{l}-1.512 \\
(0.549)\end{array}$ & $\begin{array}{l}-0.875 \\
(0.359)\end{array}$ & $\begin{array}{c}0.802 \\
(0.533)\end{array}$ & $\begin{array}{l}-0.494 \\
(1.233)\end{array}$ & $\begin{array}{c}0.554 \\
(0.106)\end{array}$ & $\begin{array}{c}1.339 \\
(0.175)\end{array}$ & $\begin{array}{c}1.491 \\
(0.345)\end{array}$ \\
\hline - July - September & $\begin{array}{c}0.245 \\
(0.099)\end{array}$ & $\begin{array}{c}0.926 \\
(0.281)\end{array}$ & $\begin{array}{c}1.252 \\
(0.149)\end{array}$ & $\begin{array}{c}0.423 \\
(0.095)\end{array}$ & $\begin{array}{c}0.629 \\
(0.367)\end{array}$ & $\begin{array}{c}0.993 \\
(0.258)\end{array}$ & $\begin{array}{c}0.38 \\
(0.267)\end{array}$ & $\begin{array}{c}1.083 \\
(0.505)\end{array}$ & $\begin{array}{c}3.212 \\
(0.727)\end{array}$ & $\begin{array}{l}1.188 \\
(0.098)\end{array}$ & $\begin{array}{c}1.062 \\
(0.180)\end{array}$ & $\begin{array}{c}1.036 \\
(0.368)\end{array}$ \\
\hline $\begin{array}{l}\text { Local unemployment rate } \\
\text { (deviation) }\end{array}$ & $\begin{array}{c}0.117 \\
(0.032)\end{array}$ & $\begin{array}{l}-0.066 \\
(0.073)\end{array}$ & $\begin{array}{c}0.104 \\
(0.041)\end{array}$ & $\begin{array}{l}-0.124 \\
(0.029)\end{array}$ & $\begin{array}{l}-0.038 \\
(0.109)\end{array}$ & $\begin{array}{l}-0.004 \\
(0.066)\end{array}$ & $\begin{array}{l}-0.063 \\
(0.081)\end{array}$ & $\begin{array}{c}0.034 \\
(0.120)\end{array}$ & $\begin{array}{c}0.012 \\
(0.089)\end{array}$ & $\begin{array}{c}-0.03 \\
(0.023)\end{array}$ & $\begin{array}{c}0.058 \\
(0.032)\end{array}$ & $\begin{array}{l}-0.043 \\
(0.061)\end{array}$ \\
\hline \multicolumn{13}{|c|}{ Deviation from trend monthly } \\
\hline GDP & $\begin{array}{l}-0.043 \\
(0.035)\end{array}$ & $\begin{array}{c}0.144 \\
(0.101)\end{array}$ & $\begin{array}{c}0.212 \\
(0.062)\end{array}$ & $\begin{array}{l}0.147 \\
(0.038)\end{array}$ & $\begin{array}{l}0.268 \\
(0.179)\end{array}$ & $\begin{array}{c}0.108 \\
(0.085)\end{array}$ & $\begin{array}{c}0.073 \\
(0.088)\end{array}$ & $\begin{array}{c}0.102 \\
(0.133)\end{array}$ & $\begin{array}{c}-0.000 \\
(0.081)\end{array}$ & $\begin{array}{c}0.104 \\
(0.032)\end{array}$ & $\begin{array}{c}0.021 \\
(0.046)\end{array}$ & $\begin{array}{c}0.05 \\
(0.088)\end{array}$ \\
\hline Constant & $\begin{array}{l}-2.575 \\
(0.293)\end{array}$ & $\begin{array}{l}-5.325 \\
(0.606)\end{array}$ & $\begin{array}{l}-4.162 \\
(0.406)\end{array}$ & $\begin{array}{l}-2.163 \\
(0.238)\end{array}$ & $\begin{array}{l}-4.322 \\
(0.788)\end{array}$ & $\begin{array}{l}-4.218 \\
(0.564)\end{array}$ & $\begin{array}{c}-3.16 \\
(0.625)\end{array}$ & $\begin{array}{l}-4.328 \\
(1.017)\end{array}$ & $\begin{array}{l}-5.253 \\
(0.998)\end{array}$ & $\begin{array}{l}-4.984 \\
(0.238)\end{array}$ & $\begin{array}{l}-5.405 \\
(0.323)\end{array}$ & $\begin{array}{l}-8.146 \\
(0.651)\end{array}$ \\
\hline \multicolumn{13}{|l|}{ Log of mass points } \\
\hline$-\ln \left(v^{2}\right)$ & $\begin{array}{c}-2.842 \\
(1.732)\end{array}$ & $\begin{array}{c}0.13 \\
(0.658)\end{array}$ & $\begin{array}{c}0.921 \\
(0.522)\end{array}$ & $\begin{array}{c}0.046 \\
(0.417)\end{array}$ & $-\infty$ & $\begin{array}{l}-0.157 \\
(1.144)\end{array}$ & $-\infty$ & $-\infty$ & $\begin{array}{c}1.096 \\
(0.587)\end{array}$ & $\begin{array}{c}-1.04 \\
(0.266)\end{array}$ & $\begin{array}{l}-2.649 \\
(0.438)\end{array}$ & $\begin{array}{l}-1.499 \\
(0.532)\end{array}$ \\
\hline$-\ln \left(v^{3}\right)$ & $\begin{array}{c}-1.362 \\
(0.218)\end{array}$ & $\begin{array}{l}-0.244 \\
(0.426)\end{array}$ & $\begin{array}{c}-0.182 \\
(0.297)\end{array}$ & $\begin{array}{c}1.087 \\
(0.261)\end{array}$ & $-\infty$ & $\begin{array}{c}0.865 \\
(0.443)\end{array}$ & $\begin{array}{c}0.594 \\
(0.419)\end{array}$ & $\begin{array}{l}-0.887 \\
(0.725)\end{array}$ & $\begin{array}{c}0.058 \\
(0.440)\end{array}$ & $\begin{array}{c}0.608 \\
(0.193)\end{array}$ & $\begin{array}{c}-0.932 \\
(0.223)\end{array}$ & $\begin{array}{l}-0.185 \\
(0.478)\end{array}$ \\
\hline \multicolumn{13}{|l|}{$\begin{array}{l}\text { Probability masses (logistic } \\
\text { transforms) }\end{array}$} \\
\hline$-\lambda^{2}$ & $\begin{array}{l}-1.032 \\
(0.278)\end{array}$ & & & & & & & & & & & \\
\hline$-\lambda^{3}$ & $\begin{array}{c}0.059 \\
(0.369)\end{array}$ & & & & & & & & & & & \\
\hline
\end{tabular}




$\begin{array}{lc}\text { - Prob(Group 1) } & 0.4137 \\ \text { - Prob(Group 2) } & 0.1474 \\ \text { - Prob(Group 3) } & 0.4389 \\ \text { Log likelihood } & -15,946 \\ \text { Number of individuals } & 1,663 \\ * \text { p }<0.10, * * p<0.05, * * * p<0.01 & \end{array}$

$* p<0.10, * * p<0.05, * * * p<0.01$

Standard errors in parentheses. Durations are divided by their standard deviation ("standardised"). The reference individual is a 15 or 16 -year-old with 5 or more A-C grade GCSEs at age 16. Household income at age 16 of the reference individual is in the highest quartile. Parents are assumed to have no qualifications and not to be working when the reference individual was 16. Estimated coefficients for some of the log mass points are shown as "- $\infty$ ". This indicates that they were constrained during estimation such that the corresponding mass point would be zero. This was done in order to aid convergence. 
Table A1b: Full estimation results showing transitions between work (w), unemployment (u), NEA (n) and education (e) for females

\begin{tabular}{|c|c|c|c|c|c|c|c|c|c|c|c|c|}
\hline & $w \rightarrow u$ & $w \rightarrow n$ & $w \rightarrow e$ & $u \rightarrow w$ & $u \rightarrow n$ & $\mathrm{u} \rightarrow \mathrm{e}$ & $n \rightarrow w$ & $n \rightarrow u$ & $n \rightarrow e$ & $e \rightarrow w$ & $\mathrm{e} \rightarrow \mathrm{u}$ & $e \rightarrow n$ \\
\hline \multicolumn{13}{|l|}{ Baseline hazard: } \\
\hline \multirow[t]{2}{*}{ - month 1} & 0.035 & & & -0.637 & & & & & & 1.422 & 1.014 & 1.59 \\
\hline & $(0.154)$ & & & $(0.182)$ & & & & & & $(0.102)$ & $(0.161)$ & $(0.222)$ \\
\hline \multirow[t]{2}{*}{ - month 2} & -0.037 & & & -0.424 & & & & & & & & \\
\hline & $(0.164)$ & & & $(0.161)$ & & & & & & & & \\
\hline \multirow[t]{2}{*}{ - month 3} & 0.04 & & & -0.048 & & & & & & & & \\
\hline & $(0.165)$ & & & $(0.142)$ & & & & & & & & \\
\hline \multirow[t]{2}{*}{ - months 1-3 } & & & & & -0.682 & 0.175 & 0.281 & -0.234 & 0.592 & & & \\
\hline & & & & & $(0.243)$ & $(0.263)$ & $(0.220)$ & $(0.305)$ & $(0.255)$ & & & \\
\hline \multirow[t]{2}{*}{ - months 4-6 } & & & & & -0.343 & 0.079 & 0.431 & -0.501 & 0.274 & & & \\
\hline & & & & & $(0.270)$ & $(0.339)$ & $(0.227)$ & $(0.420)$ & $(0.371)$ & & & \\
\hline \multirow[t]{2}{*}{ - (standardised) duration } & -1.433 & -0.664 & -1.108 & -0.82 & & & & & & 0.296 & -0.067 & 0.097 \\
\hline & $(0.198)$ & $(0.207)$ & $(0.241)$ & $(0.733)$ & & & & & & $(0.135)$ & $(0.220)$ & $(0.301)$ \\
\hline \multicolumn{13}{|l|}{ - (standardised) duration } \\
\hline \multirow[t]{2}{*}{ squared } & 0.902 & 0.411 & -0.123 & 1.165 & & & & & & 0.255 & 0.565 & 0.375 \\
\hline & $(0.205)$ & $(0.218)$ & $(0.414)$ & $(1.775)$ & & & & & & $(0.131)$ & $(0.244)$ & (0.331) \\
\hline \multicolumn{13}{|l|}{ Preceding spell: } \\
\hline \multirow[t]{2}{*}{ - Employed } & & & & 0.165 & 0.904 & -0.023 & 0.553 & 0.322 & 0.15 & & & \\
\hline & & & & $(0.171)$ & $(0.366)$ & $(0.429)$ & $(0.314)$ & $(0.530)$ & $(0.516)$ & & & \\
\hline \multirow[t]{2}{*}{ - Unemployed } & 0.758 & 0.018 & -0.52 & & & & -1.018 & -1.434 & -0.536 & & & \\
\hline & (0.199) & $(0.333)$ & $(0.398)$ & & & & $(0.576)$ & $(0.664)$ & $(0.777)$ & & & \\
\hline \multirow[t]{2}{*}{$-N E A$} & 0.179 & 0.07 & -0.141 & -0.022 & -0.492 & -2.243 & & & & & & \\
\hline & $(0.398)$ & $(0.397)$ & $(0.647)$ & $(0.436)$ & $(0.638)$ & $(1.383)$ & & & & & & \\
\hline \multicolumn{13}{|c|}{$\begin{array}{l}\text { Lagged duration dependence } \\
\text { (log months): }\end{array}$} \\
\hline \multirow[t]{2}{*}{ - Employed } & & & & 0.039 & -0.248 & -0.252 & -0.202 & -0.187 & -0.311 & & & \\
\hline & & & & $(0.067)$ & $(0.165)$ & $(0.213)$ & $(0.107)$ & $(0.206)$ & $(0.224)$ & & & \\
\hline \multirow[t]{2}{*}{ - Unemployed } & -0.222 & 0.167 & -0.322 & & & & 0.216 & 0.445 & -0.461 & & & \\
\hline & $(0.116)$ & (0.199) & $(0.267)$ & & & & $(0.290)$ & $(0.280)$ & $(0.450)$ & & & \\
\hline
\end{tabular}




\begin{tabular}{|c|c|c|c|c|c|c|c|c|c|c|c|c|}
\hline$-N E A$ & $\begin{array}{c}-0.168 \\
(0.211)\end{array}$ & $\begin{array}{c}0.125 \\
(0.167)\end{array}$ & $\begin{array}{l}-0.529 \\
(0.470)\end{array}$ & $\begin{array}{c}-0.2 \\
(0.225)\end{array}$ & $\begin{array}{c}0.221 \\
(0.244)\end{array}$ & $\begin{array}{c}0.73 \\
(0.601)\end{array}$ & & & & & & \\
\hline \multicolumn{13}{|l|}{ Age } \\
\hline$-18-21$ & $\begin{array}{c}-0.074 \\
(0.098)\end{array}$ & $\begin{array}{c}-0.031 \\
(0.141)\end{array}$ & $\begin{array}{c}-0.139 \\
(0.110)\end{array}$ & $\begin{array}{c}0.327 \\
(0.095)\end{array}$ & $\begin{array}{c}0.551 \\
(0.205)\end{array}$ & $\begin{array}{c}-0.075 \\
(0.217)\end{array}$ & $\begin{array}{c}-0.032 \\
(0.161)\end{array}$ & $\begin{array}{c}0.407 \\
(0.254)\end{array}$ & $\begin{array}{c}-0.425 \\
(0.217)\end{array}$ & $\begin{array}{c}0.194 \\
(0.110)\end{array}$ & $\begin{array}{l}-0.305 \\
(0.196)\end{array}$ & $\begin{array}{c}0.076 \\
(0.222)\end{array}$ \\
\hline-22 or over & $\begin{array}{c}-0.46 \\
(0.143)\end{array}$ & $\begin{array}{l}-0.176 \\
(0.181)\end{array}$ & $\begin{array}{l}-1.378 \\
(0.212)\end{array}$ & $\begin{array}{c}0.197 \\
(0.126)\end{array}$ & $\begin{array}{l}-0.069 \\
(0.272)\end{array}$ & $\begin{array}{c}-0.461 \\
(0.330)\end{array}$ & $\begin{array}{c}0.328 \\
(0.187)\end{array}$ & $\begin{array}{c}0.266 \\
(0.313)\end{array}$ & $\begin{array}{l}-1.057 \\
(0.343)\end{array}$ & $\begin{array}{c}0.663 \\
(0.172)\end{array}$ & $\begin{array}{l}-0.371 \\
(0.397)\end{array}$ & $\begin{array}{l}-0.583 \\
(0.418)\end{array}$ \\
\hline Children & $\begin{array}{c}-0.152 \\
(0.234)\end{array}$ & $\begin{array}{c}1.641 \\
(0.195)\end{array}$ & $\begin{array}{c}-0.532 \\
(0.541)\end{array}$ & $\begin{array}{c}-0.753 \\
(0.218)\end{array}$ & $\begin{array}{c}0.732 \\
(0.264)\end{array}$ & $\begin{array}{c}-0.658 \\
(0.596)\end{array}$ & $\begin{array}{l}-1.105 \\
(0.197)\end{array}$ & $\begin{array}{l}-1.788 \\
(0.299)\end{array}$ & $\begin{array}{l}-1.331 \\
(0.317)\end{array}$ & $\begin{array}{l}-1.156 \\
(0.428)\end{array}$ & $\begin{array}{c}0.103 \\
(0.481)\end{array}$ & $\begin{array}{c}2.237 \\
(0.316)\end{array}$ \\
\hline \multicolumn{13}{|l|}{ Qualification at age 16: } \\
\hline - Fewer than 5 A-C GCSES & $\begin{array}{c}0.209 \\
(0.126)\end{array}$ & $\begin{array}{l}-0.295 \\
(0.167)\end{array}$ & $\begin{array}{l}-0.648 \\
(0.128)\end{array}$ & $\begin{array}{c}0.031 \\
(0.119)\end{array}$ & $\begin{array}{l}-0.395 \\
(0.305)\end{array}$ & $\begin{array}{c}-0.379 \\
(0.251)\end{array}$ & $\begin{array}{l}-0.066 \\
(0.203)\end{array}$ & $\begin{array}{c}0.369 \\
(0.324)\end{array}$ & $\begin{array}{c}-0.37 \\
(0.241)\end{array}$ & $\begin{array}{c}0.577 \\
(0.083)\end{array}$ & $\begin{array}{c}0.7 \\
(0.144)\end{array}$ & $\begin{array}{c}0.284 \\
(0.183)\end{array}$ \\
\hline - CSE & $\begin{array}{c}0.826 \\
(0.149)\end{array}$ & $\begin{array}{l}-0.359 \\
(0.227)\end{array}$ & $\begin{array}{l}-1.038 \\
(0.236)\end{array}$ & $\begin{array}{c}-0.561 \\
(0.142)\end{array}$ & $\begin{array}{c}0.421 \\
(0.287)\end{array}$ & $\begin{array}{c}-0.408 \\
(0.293)\end{array}$ & $\begin{array}{l}-0.426 \\
(0.256)\end{array}$ & $\begin{array}{c}0.427 \\
(0.382)\end{array}$ & $\begin{array}{l}-0.358 \\
(0.323)\end{array}$ & $\begin{array}{c}0.826 \\
(0.121)\end{array}$ & $\begin{array}{c}1.327 \\
(0.176)\end{array}$ & $\begin{array}{c}0.686 \\
(0.241)\end{array}$ \\
\hline - none & $\begin{array}{c}0.779 \\
(0.172)\end{array}$ & $\begin{array}{c}0.364 \\
(0.221)\end{array}$ & $\begin{array}{l}-0.605 \\
(0.222)\end{array}$ & $\begin{array}{l}-0.584 \\
(0.158)\end{array}$ & $\begin{array}{c}0.417 \\
(0.294)\end{array}$ & $\begin{array}{l}-0.664 \\
(0.342)\end{array}$ & $\begin{array}{l}-0.809 \\
(0.279)\end{array}$ & $\begin{array}{c}0.114 \\
(0.372)\end{array}$ & $\begin{array}{l}-1.434 \\
(0.380)\end{array}$ & $\begin{array}{c}0.308 \\
(0.128)\end{array}$ & $\begin{array}{c}1.228 \\
(0.193)\end{array}$ & $\begin{array}{c}0.739 \\
(0.238)\end{array}$ \\
\hline Health problem, age 16 & $\begin{array}{c}0.268 \\
(0.108)\end{array}$ & $\begin{array}{c}0.218 \\
(0.151)\end{array}$ & $\begin{array}{l}-0.038 \\
(0.134)\end{array}$ & $\begin{array}{c}0.104 \\
(0.103)\end{array}$ & $\begin{array}{c}0.278 \\
(0.200)\end{array}$ & $\begin{array}{l}-0.366 \\
(0.242)\end{array}$ & $\begin{array}{c}-0.341 \\
(0.180)\end{array}$ & $\begin{array}{c}0.047 \\
(0.245)\end{array}$ & $\begin{array}{l}-0.029 \\
(0.224)\end{array}$ & $\begin{array}{c}0.093 \\
(0.082)\end{array}$ & $\begin{array}{c}0.371 \\
(0.127)\end{array}$ & $\begin{array}{c}0.532 \\
(0.158)\end{array}$ \\
\hline \multicolumn{13}{|l|}{ Household income, age 16} \\
\hline - quartile 1 (lowest) & $\begin{array}{l}-0.247 \\
(0.177)\end{array}$ & $\begin{array}{c}0.219 \\
(0.262)\end{array}$ & $\begin{array}{c}-0.251 \\
(0.182)\end{array}$ & $\begin{array}{l}-0.338 \\
(0.176)\end{array}$ & $\begin{array}{c}-0.424 \\
(0.358)\end{array}$ & $\begin{array}{c}-0.003 \\
(0.395)\end{array}$ & $\begin{array}{l}-0.587 \\
(0.281)\end{array}$ & $\begin{array}{c}-0.342 \\
(0.413)\end{array}$ & $\begin{array}{l}-0.382 \\
(0.346)\end{array}$ & $\begin{array}{c}0.204 \\
(0.121)\end{array}$ & $\begin{array}{c}0.381 \\
(0.233)\end{array}$ & $\begin{array}{c}-0.153 \\
(0.264)\end{array}$ \\
\hline - quartile 2 & $\begin{array}{c}-0.303 \\
(0.167)\end{array}$ & $\begin{array}{c}0.27 \\
(0.240)\end{array}$ & $\begin{array}{c}-0.283 \\
(0.163)\end{array}$ & $\begin{array}{l}-0.346 \\
(0.169)\end{array}$ & $\begin{array}{l}-0.038 \\
(0.344)\end{array}$ & $\begin{array}{c}0.21 \\
(0.362)\end{array}$ & $\begin{array}{c}-0.453 \\
(0.256)\end{array}$ & $\begin{array}{l}-0.549 \\
(0.394)\end{array}$ & $\begin{array}{l}-0.371 \\
(0.333)\end{array}$ & $\begin{array}{c}0.194 \\
(0.109)\end{array}$ & $\begin{array}{c}0.398 \\
(0.220)\end{array}$ & $\begin{array}{l}-0.076 \\
(0.235)\end{array}$ \\
\hline - quartile 3 & $\begin{array}{c}-0.322 \\
(0.168)\end{array}$ & $\begin{array}{c}0.146 \\
(0.244)\end{array}$ & $\begin{array}{c}-0.22 \\
(0.159)\end{array}$ & $\begin{array}{l}-0.176 \\
(0.165)\end{array}$ & $\begin{array}{c}-0.481 \\
(0.402)\end{array}$ & $\begin{array}{c}0.112 \\
(0.373)\end{array}$ & $\begin{array}{c}-0.064 \\
(0.255)\end{array}$ & $\begin{array}{l}-1.172 \\
(0.477)\end{array}$ & $\begin{array}{l}-0.197 \\
(0.323)\end{array}$ & $\begin{array}{c}0.127 \\
(0.108)\end{array}$ & $\begin{array}{c}0.222 \\
(0.225)\end{array}$ & $\begin{array}{l}-0.116 \\
(0.236)\end{array}$ \\
\hline \multicolumn{13}{|l|}{ Parent's highest qualification } \\
\hline - NVQ1 & $\begin{array}{c}-0.389 \\
(0.141)\end{array}$ & $\begin{array}{c}-0.084 \\
(0.200)\end{array}$ & $\begin{array}{c}0.161 \\
(0.185)\end{array}$ & $\begin{array}{c}0.15 \\
(0.139)\end{array}$ & $\begin{array}{l}-0.355 \\
(0.301)\end{array}$ & $\begin{array}{c}-0.174 \\
(0.314)\end{array}$ & $\begin{array}{c}0.083 \\
(0.231)\end{array}$ & $\begin{array}{c}0.306 \\
(0.337)\end{array}$ & $\begin{array}{c}-0.084 \\
(0.297)\end{array}$ & $\begin{array}{c}-0.03 \\
(0.106)\end{array}$ & $\begin{array}{l}-0.512 \\
(0.165)\end{array}$ & $\begin{array}{l}-0.027 \\
(0.219)\end{array}$ \\
\hline - NVQ2 & $\begin{array}{c}-0.454 \\
(0.203)\end{array}$ & $\begin{array}{c}-0.38 \\
(0.294)\end{array}$ & $\begin{array}{c}-0.064 \\
(0.248)\end{array}$ & $\begin{array}{c}0.287 \\
(0.193)\end{array}$ & $\begin{array}{c}0.059 \\
(0.407)\end{array}$ & $\begin{array}{c}0.004 \\
(0.408)\end{array}$ & $\begin{array}{c}-0.103 \\
(0.353)\end{array}$ & $\begin{array}{l}-0.749 \\
(0.597)\end{array}$ & $\begin{array}{l}-0.189 \\
(0.455)\end{array}$ & $\begin{array}{c}-0.032 \\
(0.142)\end{array}$ & $\begin{array}{l}-0.289 \\
(0.222)\end{array}$ & $\begin{array}{l}-0.607 \\
(0.384)\end{array}$ \\
\hline - NVQ3 & -0.434 & -0.169 & 0.173 & 0.264 & -0.175 & 0.352 & 0.289 & 0.627 & -1.193 & -0.292 & -0.733 & -0.609 \\
\hline
\end{tabular}




\begin{tabular}{|c|c|c|c|c|c|c|c|c|c|c|c|c|}
\hline & $(0.180)$ & $(0.254)$ & $(0.211)$ & $(0.164)$ & $(0.408)$ & $(0.361)$ & $(0.304)$ & $(0.435)$ & (0.519) & $(0.124)$ & $(0.216)$ & $(0.303)$ \\
\hline \multirow{2}{*}{$-N V Q 4$} & -0.497 & 0.313 & 0.407 & 0.112 & 0.224 & 0.567 & -0.158 & 0.052 & -0.038 & -0.522 & -1.077 & -0.198 \\
\hline & $(0.173)$ & $(0.222)$ & $(0.193)$ & $(0.170)$ & $(0.354)$ & $(0.326)$ & $(0.256)$ & $(0.384)$ & $(0.315)$ & $(0.115)$ & $(0.196)$ & $(0.236)$ \\
\hline \multirow[t]{2}{*}{ At age 16, parent working } & -0.242 & -0.044 & -0.016 & 0.436 & -0.171 & 0.322 & 0.618 & -0.097 & 0.692 & 0.185 & -0.425 & -0.445 \\
\hline & $(0.140)$ & $(0.200)$ & $(0.175)$ & $(0.132)$ & $(0.262)$ & $(0.276)$ & $(0.220)$ & $(0.298)$ & $(0.275)$ & $(0.105)$ & $(0.154)$ & $(0.208)$ \\
\hline \multicolumn{13}{|l|}{ Season: } \\
\hline \multirow[t]{2}{*}{ - January - March } & -0.221 & -0.33 & -1.175 & -0.266 & -1.363 & -1.636 & -0.359 & -0.501 & -0.557 & -0.776 & -0.079 & -0.42 \\
\hline & $(0.130)$ & $(0.205)$ & $(0.267)$ & $(0.121)$ & $(0.364)$ & $(0.634)$ & $(0.238)$ & $(0.407)$ & $(0.571)$ & $(0.129)$ & $(0.224)$ & $(0.322)$ \\
\hline \multirow[t]{2}{*}{ - April - May } & -0.258 & -0.152 & -1.689 & -0.208 & -1.684 & -1.344 & -0.169 & -0.829 & & 0.349 & 1.258 & 1.075 \\
\hline & $(0.132)$ & (0.198) & $(0.341)$ & $(0.124)$ & $(0.400)$ & $(0.567)$ & $(0.233)$ & $(0.440)$ & & $(0.089)$ & (0.169) & (0.219) \\
\hline \multirow[t]{2}{*}{ - July - September } & 0.364 & 0.51 & 1.495 & 0.287 & 0.452 & 1.376 & 0.617 & 0.867 & 2.189 & 0.823 & 0.748 & 0.69 \\
\hline & (0.109) & $(0.166)$ & (0.139) & $(0.105)$ & $(0.217)$ & $(0.286)$ & $(0.195)$ & $(0.292)$ & $(0.293)$ & $(0.083)$ & (0.179) & $(0.234)$ \\
\hline \multicolumn{13}{|l|}{ Local unemployment rate } \\
\hline \multirow[t]{2}{*}{ (deviation) } & 0.05 & -0.034 & 0.055 & -0.132 & 0.021 & 0.081 & -0.057 & -0.005 & 0.188 & -0.099 & 0.02 & 0.041 \\
\hline & $(0.034)$ & $(0.053)$ & $(0.038)$ & $(0.032)$ & $(0.066)$ & $(0.066)$ & $(0.061)$ & $(0.083)$ & (0.069) & $(0.022)$ & $(0.036)$ & $(0.045)$ \\
\hline \multicolumn{13}{|c|}{ Deviation from trend monthly } \\
\hline \multirow[t]{2}{*}{ GDP } & -0.026 & 0.226 & 0.129 & 0.143 & 0.203 & 0.078 & -0.02 & 0.034 & 0.235 & 0.145 & -0.03 & 0.12 \\
\hline & $(0.035)$ & (0.069) & (0.047) & $(0.039)$ & $(0.092)$ & $(0.072)$ & $(0.054)$ & $(0.088)$ & (0.101) & $(0.031)$ & (0.047) & $(0.071)$ \\
\hline \multirow[t]{2}{*}{ Constant } & -3.349 & -5.252 & -3.254 & -1.461 & -3.463 & -4.106 & -2.667 & -3.335 & -4.074 & -4.347 & -5.53 & -5.907 \\
\hline & $(0.261)$ & $(0.366)$ & $(0.275)$ & $(0.314)$ & $(0.585)$ & (0.627) & $(0.470)$ & (0.694) & $(0.576)$ & $(0.205)$ & $(0.356)$ & $(0.423)$ \\
\hline \multicolumn{13}{|l|}{ Log of mass points } \\
\hline \multirow[t]{2}{*}{$-\ln \left(v^{2}\right)$} & 1.864 & 1.227 & 0.666 & 0.209 & 0.752 & 0.769 & 0.772 & $-\infty$ & 0.183 & -0.558 & 1.72 & $-\infty$ \\
\hline & $(0.278)$ & (0.401) & $(0.403)$ & $(0.250)$ & (0.629) & $(0.462)$ & $(0.381)$ & & (1.031) & (0.334) & $(0.322)$ & \\
\hline \multirow[t]{2}{*}{$-\ln \left(v^{3}\right)$} & -0.374 & -0.015 & -0.701 & 0.318 & $-\infty$ & -0.205 & -0.557 & $-\infty$ & -0.022 & -1.09 & -1.458 & -1.295 \\
\hline & $(0.321)$ & (0.375) & $(0.463)$ & $(0.328)$ & & $(0.776)$ & $(0.398)$ & & $(0.511)$ & $(0.279)$ & $(0.434)$ & (0.519) \\
\hline \multirow[t]{2}{*}{$-\ln \left(v^{4}\right)$} & 1.18 & 0.055 & -0.11 & -1.14 & -0.077 & -0.059 & -1.355 & 0.217 & 0.414 & -0.713 & 0.967 & 0.721 \\
\hline & $(0.283)$ & $(0.520)$ & $(0.361)$ & $(0.191)$ & $(0.416)$ & $(0.397)$ & $(0.606)$ & (0.538) & $(0.307)$ & $(0.253)$ & (0.359) & $(0.361)$ \\
\hline \multicolumn{13}{|l|}{$\begin{array}{l}\text { Probability masses (logistic } \\
\text { transforms) }\end{array}$} \\
\hline \multirow[t]{2}{*}{$-\lambda^{2}$} & 3.068 & & & & & & & & & & & \\
\hline & 401 & & & & & & & & & & & \\
\hline
\end{tabular}


$-\lambda^{3}$

$-\lambda^{4}$

\section{Resulting probabilities:}

$\begin{array}{lc}\text { - Prob(Group 1) } & 0.539 \\ \text { - Prob(Group 2) } & 0.025 \\ \text { - Prob(Group 3) } & 0.275 \\ \text { - Prob(Group 4) } & 0.161 \\ \text { Log likelihood } & -18,723 \\ \text { Number of individuals } & 1,811 \\ * p<0.10, * * p<0.05, * * * p<0.01 & \end{array}$

$-0.672$

(0.369)

$-1.208$

(0.496)

0.539
${ }^{*} p<0.10, * * p<0.05, * * * p<0.01$

Standard errors in parentheses. Durations are divided by their standard deviation ("standardised"). The reference individual is a 15 or 16 -year-old with 5 or more A-C grade GCSEs at age 16. Household income at age 16 of the reference individual is in the highest quartile. Parents are assumed to have no qualifications and not to be working when the reference individual was 16. Estimated coefficients for some of the log mass points are shown as "- $\infty$ ". This indicates that they were constrained during estimation such that the corresponding mass point would be zero. This was done in order to aid convergence. 
Appendix A2 - the effects of prior status and lagged duration dependence when not controlling for unobserved heterogeneity or other regressors

Table A2a shows, for males, the estimated effects of preceding state and its duration when excluding unobserved heterogeneity (top panel) and excluding both unobserved heterogeneity other characteristics $X$ (bottom panel). A comparison with Table 5 shows the importance of controlling for unobserved heterogeneity; doing this results in the lagged duration terms in the employment to unemployment transition intensity becoming statistically significant, for instance. Furthermore, a comparison across the panels of Table A2a shows how controlling for observed characteristics changes the estimated effects of prior experience, most notably with the estimated effect on the unemployment to employment transition intensity of having previously been employed. For females, Table A2b similarly shows that controlling for unobserved heterogeneity changes the estimated effect of prior experience. For instance, comparing Table 5 with the top panel of Table A2b shows that lagged employment duration is no longer statistically significant in the unemployment to employment transition after controlling for unobserved heterogeneity. An example of the role of observed characteristics is lagged NEA duration being significant in the transitions from unemployment to employment and NEA before controlling for $X$ (bottom panel) but not after (top panel).

Tests confirms the significance of unobserved heterogeneity. A comparison of the full model with the model excluding unobserved heterogeneity gives a likelihood ratio test statistic of 82.8 (22 degrees of freedom) for males and 76.8 (35 degrees of freedom) for females. Comparing the model without unobserved heterogeneity with the model without unobserved heterogeneity and without $X$, gives a likelihood ratio test statistic of 1,032.5 (228 degrees of freedom) for males and 1,357.8 (240 degrees of freedom) for females. All tests are statistically significant at the 99 per cent level. 
Table A2a: The effect of prior status and lagged duration dependence in transition intensities between work (w), unemployment (u), NEA ( $n$ ) and education (e), males

$\begin{array}{rrrrr}w \rightarrow \mathrm{w} & \mathrm{w} \rightarrow \mathrm{n} & \mathrm{w} \rightarrow \mathrm{e} \quad \mathrm{u} \rightarrow \mathrm{w} \quad \mathrm{u} \rightarrow \mathrm{n} \quad \mathrm{u} \rightarrow \mathrm{e} \quad \mathrm{n} \rightarrow \mathrm{w} \\ \text { a) No unobserved heterogeneity, log-likelihood }= & -16,028.81\end{array}$

Preceding spell:

- Employed

- Unemployed

$\begin{array}{lllllllll} & & & 0.266 * * & -0.8 & 0.132 & 0.664^{*} & 2.047^{* * *} & 0.279 \\ 0.743^{* * *} & -0.067 & -0.248 & & & & 0.835 & 0.301 & -0.283 \\ 1.019 * & -0.306 & -0.8 & 1.541^{* * *} & 1.018 & -0.086 & & & \end{array}$

- NEA

1.019*

$-0.306$

$-0.8$

$1.541^{* * *} \quad 1.018$

$-0.221$

- Employed

- Unemployed

$0.061 \quad 0.012 \quad-0.538^{* *}$

0.08

0.127

$-0.221$

0.029

$-0.518^{* *}-0.244$

- NEA

$-0.712 *$

0.731

$-0.797^{* * *}-0.223$

0.402

b) No unobserved heterogeneity, no X. Log-likelihood $=-17,061.298$

\section{Preceding spell:}

- Employed

- Unemployed

- NEA

$\begin{array}{ll}0.703 * * * & -0.197 \\ 0.92 & -0.243\end{array}$

$-0.651^{*}$
-0.593

$0.086-0.77$

0.37

$1.756 * * * \quad 0.111$

0.92

$-0.243$

$-0.651^{*}$
-0.593

0.592

0.254

0.36

$-1.446$

Lagged duration dependence (log months):

- Employed

- Unemployed

$\begin{array}{lll}0.132 * & 0.043 & -0.448^{*} \\ -0.703 * & 0.715 & 0.076\end{array}$

$0.159 * * * \quad 0.198$

$-0.188$

0.023

$-0.587$

$-0.444^{* *} \quad-0.5^{* *}$

$-0.703 * \quad 0.715$

$-0.822 * * * \quad 0.166$

0.057

${ }^{*} \mathrm{p}<0.10,{ }^{* *} \mathrm{p}<0.05,{ }^{* * *} \mathrm{p}<0.01$. Cell entries are the estimated coefficients from the model estimated without unobserved heterogeneity (top panel) and without unobserved heterogeneity or observed characteristics (bottom panel). 
Table A2b: The effect of prior status and lagged duration dependence in transition intensities between work ( $w$ ), unemployment ( $u$ ), NEA ( $n$ ) and education (e), females

$w \rightarrow u$

$w \rightarrow n$

$\mathrm{w} \rightarrow \mathrm{e}$

$\mathrm{u} \rightarrow \mathrm{w}$

a) No unobserved heterogeneity. Log-likelihood $=-18,799.819$

\section{Preceding spell:}

- Employed

- Unemployed

- NEA

Lagged duration dependence (log months):

- Employed

- Unemployed

- NEA

$0.851 * * * \quad 0.15 \quad-0.393$

0.433

0.334

0.068

0.034

$1.009 * * * \quad 0.085$

$0.804^{* * *} \quad 0.257 \quad 0.067$

$-0.431 \quad-1.337^{* *}-0.503$

$\begin{array}{lll}0.08 & -0.415 & -2.257\end{array}$

$\begin{array}{lll}-0.067 & 0.136 & -0.35 \\ -0.169 & 0.039 & -0.611\end{array}$

$0.116^{* *}$
$0.116^{* *}$

$-0.284^{*}$

$-0.304$

$-0.203^{* *} \quad-0.219$

$-0.32$

$-0.326$

0.228

0.712

b) No unobserved heterogeneity, no X. Log-likelihood =-20,157.591

\section{Preceding spell:}

- Employed

Lagged duration dependence (log months):

- Employed

- NEA

$0.747 * * * \quad 0.061$

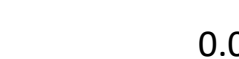

0.049

0.36

$-0.332$

$0.456 *$

$-0.139$

$-0.847^{*}$
- Unemployed

- NEA

- Unemployed

0.21

0.416

$-0.743 * *$

0.159

0.342

$-0.535$

$-1.969$

0.047

$0.195-0.372$

$0.15^{* * *} \quad-0.043$

$-0.261$

$\begin{array}{llllll}-0.145 & 0.416 * * * & -0.978 * * & -0.535 * * * & 0.467 * * & 0.244\end{array}$

$\begin{array}{llllll}-0.145 & 0.416 * * * & -0.978 * * & -0.535 * * * & 0.467 * * & 0.244\end{array}$

$\begin{array}{llllll}-0.145 & 0.416 * * * & -0.978 * * & -0.535 * * * & 0.467 * * & 0.244\end{array}$

$\begin{array}{llllll}-0.145 & 0.416 * * * & -0.978 * * & -0.535 * * * & 0.467 * * & 0.244\end{array}$

$-0.34-1.488 * *-0.778$

${ }^{*} \mathrm{p}<0.10,{ }^{*} \mathrm{p}<0.05,{ }^{* * *} \mathrm{p}<0.01$. Cell entries are the estimated coeffic
unobserved heterogeneity or observed characteristics (bottom panel). 